\title{
Late Pleistocene evolution of the mixed siliciclastic and carbonate southwestern New Caledonia continental shelf/lagoon
}

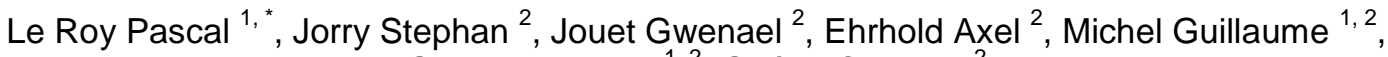 \\ Gautier Valentin ${ }^{1,2}$, Guérin Charline ${ }^{2}$
}

\author{
${ }^{1}$ Université Européenne de Bretagne Occidentale, UMR-6538 Domaines Océaniques, IUEM/CNRS, \\ Place Copernic, 29280 Plouzané, France \\ 2 IFREMER, Géosciences Marines, Centre de Brest, BP70, 29280 Plouzané, France \\ *Corresponding author : Pascal Le Roy, email address : leroy@univ-brest.fr
}

\begin{abstract}
:
The main island of New Caledonia (NC) is surrounded by the second largest barrier reef in the world after the Australian Great Barrier Reef. The Upper Pleistocene evolution of this barrier reef-lagoon complex offers the opportunity to examine the response of a modern mixed tropical siliciclastic/carbonate system to relative sea-level changes and to better constrain the relative role of lagoon backfilling and paleo-drainage system in sediment transfer across the shelf. This paper mainly focuses on the results of chronostratigraphic and sedimentological interpretations of new seismic, bathymetric and coring data collected in the SW NC lagoon. Several significant points are highlighted from this study and allow the construction of a refined model which includes the evolution of both the SW NC mixed shelf and lagoon. New results show that the NC lagoon has not recorded a reciprocal sedimentation during glacial-interglacial sea-level cycles but a unique mixed regime. Strong contrasts are observed and these depend above all on the two lagoon domains: the outer coral plateau and the inner lagoon depression corresponding to a semi-closed proximal basin which is separated from the plateau by a basement ridge. In the depression, clastic sediments remain dominant from early flooding to highstand stages while carbonate sedimentation continued through time across the coral plateau. This spatial contrast between terrigenous and carbonate deposits was maintained throughout various sea level cycles. Thus, even if spatial segregation is also observed for other examples of mixed shelf environments, the SW NC shelf appears quite unique in comparison to the other mixed systems when considering conceptual models of reciprocal sedimentation. Moreover, the presence of a semi-enclosed lagoon depression allows the preservation of larger volume of terrigenous deposits. This semi-filled geometry of the lagoon is assumed to be the result of several factors: a significant subsidence that offers accommodation for aggrading deposits, evacuation through channels of sediments mobilized during storm events, the tidal currents, and fairweather wave dynamics. Lastly, the inherited morphologic and structures may explain the geomorphic evolution of the "escarpment margin" type of the SW NC rimmed shelf and its differentiation with the opposite SE NC ramp type shelf.
\end{abstract}




\section{Highlights}

- A semi-filled lagoon geometry Differs from general conceptual model of reciprocal sedimentation of mixed sliclastic/carbonate system $>$ Strong spatial contrast between clastic inner lagoon depression and outer lagoon coral plateau

Keywords : Seismic stratigraphy, Quaternary, Incised valleys 


\section{Introduction}

Mixed tropical siliciclastic/carbonate systems are relatively common in the geological record where carbonate platforms were developed along continental shelves with continuous or ephemeral terrigenous sediments (Catuneanu et al., 2011). The lithofacies succession of such systems and the related continental print are strongly controlled by amplitude, rate of sea-level change, clastic inputs, sediment transfer, erosion, and oceanographic conditions (Van Siclen, 1958; Schlager et al., 1994; Catuneanu et al., 2011; Droxler and Jorry, 2013). Nevertheless, compared to pure siliciclastic or carbonate systems, the evolution of sediment transfer and depositional models along shelf-margin mixed systems remains poorly documented and represents challenging in terms of understanding the cyclicity of reciprocal sedimentation (carbonate vs siliclastic) and the detailed sedimentary response of such shelves to glacialinterglacial sea-level cycles (Wilson, 1967; Mount, 1984; Doyle and Roberts, 1988; Schlager et al., 1994; Francis et al., 2007; Droxler and Jorry, 2013; D’Agostini et al., 2015).

As pure siliciclastic shelves, the majority of such mixed shelves are characterized by paleo-drainage networks that incised the seafloor at the base of modern lagoons. They are assumed to have been carved by the development of rivers during Pleistocene sea-level lowstands (e.g., Larcombe and Carter, 1998; Esker et al., 1998; Zinke et al., 2001; Le Roy et al., 2008; Toomey et al., 2016; Hinnestrosa et al., 2016). These palaeo-drainage networks are connected downstream to deep inlets along the barrier reef. The inherited morphology of the channels played a crucial role in controlling the reef development by affecting sediment stability, local circulation, and availability of substrate for the growth of the reef during subsequent sea level rises (Hinnestrosa et al., 2016; Droxler and Jorry, 2013). These networks also delineate the main pathways for water exchanges during highstands and act as axes for terrigenous sediment transfer to the deep sea when the carbonate shelf is subaerially exposed during lowstands. As a consequence, preserved lowstand terrigenous deposits are mostly considered as limited on continental shelves and are restricted to channel lag deposits observed on 
high-resolution seismic lines (Zinke et al., 2001). Moreover, these paleo-valley systems could have extended locally across the entire shelf, as in the French Polynesia Tahha barrier reef (Toomey et al., 2016), and acted as exclusive routes of terrigenous fluxes during lowstands. This is also observed along the slopes and basins in the Caribbean, where clastic input toward the deep sea was much greater during glacial times (Schlager et al., 1994). These results are in agreement with the Van Siclen (1958) and Wilson (1967) conceptual sedimentation models of the cyclic-reciprocal sedimentation of tropical mixed carbonate-siliciclastic shelves, where carbonate sedimentation dominates during transgressions and highstands, and siliciclastic deposits are predominant along slopes and basins during lowstands. However, other field observations do not fit with this conceptual model, and the occurrence of terrigenous deposits along continental shelves have been described for sea-level highstands that allow lagoonal infilling by siliciclastic material in nearshore areas. This scenario has been observed in Mayotte (Zinke et al., 2001), along the northern Brazilian Abrolhos shelf (D'agostini et al., 2015), and for the Great Barrier Reef (Larcombe and Carter, 1998; Francis et al., 2007; Dunbar and Dickens, 2003). As mentioned by D'Agostini et al. (2015), this paradox shows that the response of mixed tropical siliciclastic/carbonate systems to relative sea level changes varies considerably, and they point out that the evolution of such mixed shelves and the relative roles of lagoon backfilling and paleo-drainage systems with regard to sediment transfer needs to be more documented and constrained. The Upper Pleistocene evolution of the New Caledonia barrier reef-lagoon complex offers the opportunity to complete this approach. Located in the SW Pacific, the NW-SE-trending main island of New Caledonia (NC), 'Grande Terre', is surrounded by the second largest barrier reef in the world after the Australian Great Barrier Reef (Coudray, 1976), (Fig. 1). This barrier reef is almost continuous, and locally comprises double or even triple parallel barrier reefs. This wide lagoon (up to $40 \mathrm{~km}$ ) is a typical example of a shallow rimmed shelf bounded by very steep slopes corresponding to the 'escarpment margins' type of carbonate platform, as defined by Emery (1996). Previous studies suggest the first occurrence of coral reef tracts around $400 \mathrm{cal} \mathrm{kyr}$, B.P. or Marine Isotope Stage 11 (MIS11) (Montaggioni et al., 2011), and lagoon development only after the two last 100 ka eustatic cycles, around MIS7 (Le Roy et al., 2008).

Two seismic depositional sequences have been previously defined in the lagoon (Le Roy et al., 2008), and only the upper one can be divided into three system tracts (lowstand, transgressive, and highstand). Deep valleys reaching up to $80 \mathrm{~m}$ below sea level (b.s.l.) connect 
the outer NC lagoon to the continental slope through the passes (Avias, 1959; Dugas et al., 1980; Lafoy et al., 2000; Chevillotte et al., 2005). The presence of shallow meandering paleo-channels cut by deepening linear valleys marks the occurrence of fluvial drainage networks developed close to the slope failure at the shelf break. Previous work revealed that NC rivers did not incise the inner shelf, suggesting a decoupling of upland river systems and lagoonal channels that propagated until the barrier edge. A nearshore aggrading alluvial wedge cut by numerous superficial channels is thought to have developed along a coastal and/or alluvial plain built during the last glacial maximum in front of coastal foothills and located at the mouth of continental valleys (Le Roy et al., 2008). This sedimentary evolution differs from the classic model of reciprocal sedimentation of mixed terrigenous/carbonate sediments with lowstand shedding of clastics and lowstand wedges restricted to the margin slope and basin floor (Van Siclen 1958). These results were based on geophysical data and first interpretations, which required constrains by core sampling. This paper mainly focuses on the results of chronostratigraphic and sedimentological interpretations of new data collected in the SW NC lagoon. In addition to sediment cores, new seismic and bathymetric data also contribute to refine the model of the SW NC lagoon evolution. The interplay of inherited morphology with late Quaternary sea-level fluctuations and the implications for shelf and reef development are discussed, and a comparison is made with other mixed siliciclastic/carbonate systems.

\section{Methodology}

The CALICO (CALedonian Coring) cruise was carried out from the $14^{\text {th }}$ to the $27^{\text {th }}$ of October 2013 aboard the French RV L'Alis. A Kullenberg system with a $3 \mathrm{~m}$ barrel was used to perform the coring. Nine cores were used in this work (Fig 2 and Tab.1). The PVC liner was split in half longitudinally for core examination and description. Although rather short, the sediment cores have been used to calibrate the sedimentary facies of the upper seismic sequences. Samples were also analyzed with a laser granulometer.

The AMS ${ }^{14} \mathrm{C}$ measurements were conducted at the Poznan radiocarbon laboratory (Poland). Analyses were performed on preserved marine shells (mainly bivalves and gastropods, Tab. 2). ${ }^{14} \mathrm{C}$ ages were calibrated using the Calib Rev 7.0.4 software (Stuiver et al., 2013; Reimer et al., 2013). 
Seismic acquisition was performed with a very high-resolution seismic source (Sparker Source) that included a single-channel SIG streamer and a numerical DELPH acquisition system. The sparker emission energy ranged from 250 to $160 \mathrm{~J}$, the shooting rate ranged from 330 to $500 \mathrm{~ms}$, and the vessels bottom speed was 5 knots. Seismic processing (gain control, filtering -400-1500 $\mathrm{Hz}-$, swell correction) was carried out with DELPH processing software and interpreted using Kingdom Suite software (Seismic micro technology INC). Seismic sequences were identified using criteria outlined by Mitchum et al. (1977a, 1977b), Posamentier and Vail (1988), and Van Wagoner et al. (1988), while terminology from Catuneanu et al. (2011) was used for the description of depositional sequences. Seismic lines are displayed with two-way travel time in ms. Despite a lack of accurate P-wave velocity data from the investigated formations, the time-depth conversions described in this paper assume an average velocity of $1800 \mathrm{~m} / \mathrm{s}$ for unconsolidated sediments. According to Anselmetti and Eberli (1997) and Zinke et al. (2001), a P-wave velocity of $3000 \mathrm{~m} / \mathrm{s}$ can be considered as representative of a consolidated reef framework (boundstones textures). Multibeam bathymetry was acquired using a Kongsberg-Simrad EM 1002 system linked to a fixed inertial central system. The total swath width was about $140 \mathrm{~m}$ in a water depth of $20 \mathrm{~m}$. The seismic lines and swath bathymetry were acquired including the main SW pass systems of Boulari and Dumbéa (Fig. 2), and extended to the Island of Pines, southward. The multibeam baythymetry was processed using SONARSCOPE software (Ifremer). The water depths mentioned in the paper are expressed in meters below present mean sea level (mbsl).

\section{Geological setting of the SW New-Caledonian continental shelf and previous work}

Located in the South-West Pacific, the main island of New Caledonia or "Grande Terre" extends between $20^{\circ}$ and $23^{\circ}$ South (Fig.1). It belongs to the NW-SE-trending New Caledonia ridge and corresponds to the northern emerged segment of the Norfolk ridge, a major scar of the Australian plate that subducts below the Pacific plate within the Vanuatu trench at a rate of 12 $\mathrm{cm} / \mathrm{yr}$ in the ENE direction (Calmant, 2003). The SW continental shelf of the New Caledonia island exposed to the SE trade winds includes the widest segment of the NC lagoon, the Nouméa Lagoon, which extends from the Saint-Vincent pass in the north (8 $\mathrm{km}$ wide) to the Corne Sud domain at its southern end (60 km wide) (Fig. 1). The depth of the lagoon between the passes of St Vincent and Mato is about $17.5 \mathrm{~m}$ (Lowest Astronomical Tide) on average and does not exceed 
$30 \mathrm{~m}$. South-eastwards of the Mato pass, the depth increases to an average of about $35 \mathrm{~m}$ and more than $50 \mathrm{~m}$ in the Corne Sud area. Apart from the latter area, where the morphology of the shelf corresponds to a ramp system, the SW lagoon is characterized by an inner section comprising enclosed bays and an outer reef lagoon which is sheltered from the open sea by a narrow reef-barrier of a few kilometers wide, emerging at low tide- The overall system is dissected by extended palaeo channel systems connected to narrow passages (so called passes) at water depths reaching more than $80 \mathrm{~m}$, which include the passes of Uitoé, Dumbéa, Boulari, and Mato (Figs. 1 and 3). The passes and connected channels are now active as tidal inlets, with currents reaching up $80 \mathrm{~cm} / \mathrm{s}$ despite the microtidal regime (Rougerie, 1986).

The outer lagoon can be divided into two 'domains' according to Dugas and Debenay (1978), which include: (1) the coral plateau close to back reef areas at water depths of about $20 \mathrm{~m}$ and (2) a deeper lagoon depression close to the coastline at more than $20 \mathrm{~m}$ water depth (Fig. 3). Such a depression corresponds to the Bangail Bay extending between the Mont Dore Peninsula and Ouen Island (Fig. 3). It is characterized by mean water depths exceeding $25 \mathrm{~m}$ and is separated from the coral plateau by several coral islands (Kaé, Tareti, Nakaé) forming a shallow (mean water depths above $-15 \mathrm{~m}$ ) discontinuous $\mathrm{N} 140^{\circ}$-trending ridge whose basement remains undocumented and unknown. Other patch-reef complex are scattered across the lagoon (Fig.3) (Andrefouët et al., 2008). Surface sediments of the coral plateau are made up of well-sorted whiteyellowish and grey coral sands, while sediments of the depression corridor are composed of sandy ooze (Debenay, 1987). The inner lagoon corresponds to continental fringing reefs and bays where coastal plains and mangroves are typical features in some places. The inner lagoon is bounded by steep continental hills reaching several hundreds of meters in elevation.

Several sediment cores were collected in the barrier reef, showing that it is composed of successive layers of reef units developed during sea level highstands (Avias et Coudray, 1967; Coudray, 1976; Cabioch et al., 1996; Payri and Cabioch, 2004; Frank et al., 2006). Recent results based on the study of a new core (Ténia 3 core, $151.20 \mathrm{~m}$ long, located on the Tenia island, Fig.1) have shown that carbonate deposition prior to MIS11 (400 cal kyr, B.P) is considered to have operated along an open shelf margin, i.e. a Pleistocene ramp or non-rimmed platform according to Montaggioni et al. (2011). The initiation of typical coral reef tracts and the associated reef-rimmed platform are likely to have begun after this stage (Montaggioni et al., 2011), i.e. the Mid-Brunhes Event. Along with growth of the 
barrier reef, the interpretation of seismic data coupled with chronological data available in the cores retrieved on the barrier reef and in estuarine bays suggests that the age of the largest part of the lagoon does not exceed 200 ka (Le Roy et al., 2008). The dissimilar ages of the lagoon and reef can be reconciled with the differential subsidence of the shelf-margin, ranging from $0.07 \mathrm{~mm}^{-1} \mathrm{close}^{-10}$ shoreline to $0.12-0.16 \mathrm{~mm} \mathrm{yr}^{-1}$ along the barrier reef (Coudray, 1976; Chevillote et al., 2005; Le Roy et al., 2008; Montaggioni et al., 2011). As a consequence, the progressive tilt of the shelf allowed its continued flooding and correlative lagoon development during the successive Middle and Upper Pleistocene sea-level highstands. This evolution is in agreement with the hypothesis of the 'piano keys' structural style of Grande Terre, composed of structural blocks characterized by differential movements (Cabioch et al., 1998). This differential tectonic behaviour could be related to still active post-obduction isostatic readjustments. It follows the emplacement of a large allochthones sheet of oceanic lithosphere during Upper Eocene onto arc-derived continental terranes (Paris, 1981, Cabioch et al., 1996).

Previous works have also shown that shelf subsidence subsequent to the barrier reef edification and changes in the lagoon morphology enclosing the inner reef structures have contributed to the modification of the paleo-channels directions across the lagoon, from a NW-SE to NNE-SSW trend. Although seismic surveys did not show any evidence of normal faults or graben structures controlling the formation of incised channels, the structural framework and inherited structural directions seem to have controlled the geometry of the main streams (Chevillote et al., 2005; Le Roy et al., 2008).

\section{Results}

\subsection{Bathymetric data}

Multibeam bathymetric data collected during the CALICO cruise enable the visualization of the morphology of the Boulari and Dumbéa paleo-channels and the connection of the "5-miles channel" with the Corne Sud area (figs 2 and 3).

The Dumbéa system clearly shows numerous interlaced sinuous channels that approximate an anastomosed pattern terminating the incised system at mean water depths ranging from 22 to $25 \mathrm{mbsl}$ (fig 4). Channels of the upstream system are less than 10 meters deep 
and show progressive terminations without an upstream incised continental junction. These channels have high width/depth (W/D) ratios of approximately 50-100 with a relatively low sinuosity (1.1 or less). Our data clearly show that the Dumbéa upstream drainage system has developed between patch reefs and small islands where previous cores drilled through coral reef formations of the Noumea lagoon revealed the presence of a 3 to $5 \mathrm{~m}$ thick modern reef overlying older Pleistocene (125 ka or more) carbonate units (reef and reefal sediments) (Castellaro, 1999, Cabioch et al., 1999, Andrefouet et al., 2009). The longitudinal-section of the main channel shows that the incision extends through the coral plateau from the inner lagoon depression up to the reef barrier where the water depth of the channel reaches $80 \mathrm{~m}$ and is marked by a low W/D ratio of 10. An apparent knickpoint is located $10 \mathrm{~km}$ landward from the outer pass with depths increasing from 50 to $65 \mathrm{~m}$

The depth of the channel incision needs to be corrected using an additional value corresponding to the sedimentary fill settled in the channel during the MIS 2 (Last Glacial Maximum) or following stages. It is estimated at about $10 \mathrm{~m}$ from seismic data along the reef barrier. However, on the contrary, the thickness of the Holocene reef of about $15 \mathrm{~m}$ along the barrier reefs suggests that the incision was lower and reached a maximum value of $75 \mathrm{~m}(=80+10-15 \mathrm{~m})$ through the old barrier reef units during the MIS 2.

The Boulari system exhibits a dichotomous shape, with two N/S and E/W-trending tributaries that flow into a deep and wide major valley (Fig 5). The detailed bathymetric map of the Boulari system (only the eastern tributary was fully surveyed) displays a section of the valley upstream of the confluence point. It shows two large meanders with a sinuosity close to 1.8. The incised channel extends from the lagoon depression between patch reefs and the channel depths grade from a few meters to 40 to $45 \mathrm{~m}$ close to the joining junction point. The upstream network of the Boulari system ends progressively through the lagoon depression where a few channels reaching 2 to $3 \mathrm{~m}$ of incision are visible (Fig. 5a). These terminations are masked by a spotted morphology characterised by domes, which extend through most parts of the depression area. The domes are 2-4 $\mathrm{m}$ high and have a diameter of about a decameter. The W/D ratio of the Boulari upstream channel is still low (50-100) and several perched fossilized meanders are also visible at depths of 30-32 m on both flanks of the incised paleo-valley (Fig. 5b). Channel-bar systems are also clearly shown along the concave meanders. They are a few-meters high and about 50-100 m wide with elongated downstream spits (fig 
5b). Modern reefs have accreted above the top of the channel flanks and some small patches interpreted as coral bioherms are also identified on the channel bars and stepped meanders (Fig. 5b). A knickpoint is located at the joining point and corresponds to the transition of the mean depths of the channels (eastern and western tributaries) from 40-45 m to $65 \mathrm{~m} .$. In contrast, and as mentioned before by Le Roy et al. (2008), the downstream channel widens up to $2 \mathrm{~km}$-wide, meanwhile the channel is hemmed in at water depths over $70 \mathrm{~m}$ and exhibits a meandering geometry with abrupt bends and stepped preserved terraces at 32-34 m and 40-45 m (Fig. 5c).

As is the case in the Boulari system, the 5-miles channel extends from the Lagoon depression and links the Corne-Sud area at the east of Grande Terre. It is noted that the nearby Woodin channel (Fig. 3) used as the present day main sailing communication axis between the SW and E lagoons does not show any incised paleo-valleys, however a bathymetric threshold attests to its recent flooding.

The 5-miles channel exhibits a singular $L$ shape. It reveals the control of the incision process from the inherited morphology of Pleistocene reefs, themselves constrained by the structural framework of the tertiary basement that outcrops on the nearby Mato and Uo islands, located south of the 5-miles channel. The narrow valley, $100-300 \mathrm{~m}$ wide, is surrounded by two reefs with an elevation of more than $17 \mathrm{~m}$, located along the two steep channel flanks (Fig 6). They amplify the water depth of the channel $(35 \mathrm{~m})$ relative to the incision, which is in reality about $20 \mathrm{~m}$ deep compared to the surrounding seabed. The 5 -miles channel is terminated by a bathymetric scarp of about 10 meters bounding the reef located south of Ouen Island. Water depths vary from $50-55 \mathrm{~m}$ to $65 \mathrm{~m}$ and the incision decreases to a few meters. Nevertheless, the continuity of the meandering channel can be identified up to the shelf edge located at a water depth of $100 \mathrm{~m}$, at a distance of more than $30 \mathrm{~km}$ from the bathymetric scarp. Two large elongated depressions are also visible within the coral plateau in the vicinity of the channel: the northern "Basse La" depression $(9 \times 5 \mathrm{~km})$ is about $10 \mathrm{~m}$ deep and the Mato depression (18x5 km) to the south is about $20 \mathrm{~m}$ deep (Fig. 1). Both depressions exhibit curving shapes,

\subsection{Seismic stratigraphy}

Interpretation of seismic lines is based upon the classification used during the previous CALGON survey (CALedonian LaGOoNn) (Le Roy et al., 2008) and three types of seismic units 
are identified according their outer geometry: sheet geometry type with locally associated bank geometry, channel fill type, and mound type.

The new data acquired with the Very High Resolution sparker system allow the depiction of details of the sedimentary infill through the upstream channel systems and the coastal depressions.

Correlations are based on upper or lower well reflective bounding surfaces and the compilation of seismic data sets. Figures 7 and 8 display representative examples of seismic lines through the Boulari system with a cross-shore composite seismic line. Figure 9 shows complementary extracts of the Dumbea and 5-miles channel systems. Figure $10(A)$ shows a synthetic view of the depicted seismic stratigraphy with a summary table (C), the lower scheme (Fig. 10B) corresponding to the sequence stratigraphy model of the SW lagoon.

\subsubsection{Sheet type units (sh type)}

Five units of this type are identified from, the base to the top (Fig. 10C):

- a unit sh1, marked by chaotic reflectors with low continuities, weak to variable amplitudes and low frequencies. It corresponds to the acoustic basement $(\operatorname{Pr} 138$, Fig. 7, composite line, Fig. 8, Line $\operatorname{Pr}$ 36, Fig. 9).

- a unit sh2, bounded at the base by the R1 reflector. The unit is identified locally at the base of the Boulari lagoon depression with low amplitude and continuous reflectors (Figs. 7and 8). - a unit sh3, bounded at the base by the $\mathrm{R} 2$ reflector. The $\mathrm{R} 2$ reflector is a prominent marker bounding the overlying layered sedimentary package and is identified at a relative constant depth of about 75/80 ms through the Boulari lagoon depression (line Pr 138, Fig.7). It extends below the channel fill units ( $\operatorname{Pr} 107$, Fig.7) and rises up to a depth of 50/60 ms in most parts of the surveyed areas close to the present coastline (e.g. line Pr 36, Fig 9). The sh3 unit is subdivided in two subunits, sh3.1, and sh3.2 characterized by contrasting seismic facies. The sh3.1 sub-unit, exists in the coral plateau, and shows reflectors with high amplitudes, low frequencies, and moderate continuities (line Pr88, Fig.8), while the sub-unit sh3.2 is restricted to the Boulari lagoon depression, and is continuous to chaotic discontinuous reflectors with cut and fill facies in a general aggrading pattern.

- a unit sh4 with a general aggrading geometry that extends through the entire shelf. Seismic facies are quite similar to the unit sh3, with again the individualization of a subunit, sh4.2, through 
the Boulari lagoon depression marked with discontinuous cut and fill facies. The distinction between the subunits sh4.2 and sh3.2 is only clearly visible along the long-shore profiles crossing the Boulari lagoon depression (Fig.7). Locally, along the flanks of the channels, the subunit sh4.1 inner reflectors show dipping sigmoid-oblique to oblique-parallel clinoforms that define a progradation with a bank geometry orientated toward the channel axis (Fig. 7).

- a unit sh5whose base is bounded by a strong south-westward dipping erosional unconformity R4 with a local channelling morphology. This unit is composed of a set of changing seismic facies with reflectors varying from low continuities and amplitudes to high amplitudes and clear continuities. The unit sh5 depicts a remarkably rough facies at the top of the Boulari lagoon depression where it corresponds to bioherms identified on bathymetry. Two sub-units, sh5.1 and sh5.2, are locally identified with a draping subunit sh5.2 overlying an R5 reflector. Finally, a lateral change of seismic facies is also observed along the downstream extension of the 5-miles channel where a chaotic facies is located at the base of a $50 \mathrm{~ms}$ (twice-time) elevated scarp,

\subsubsection{Channel fill type unit (ch type)}

Seismic interpretation shows evidence of two successive generations of incised channels developed through the lagoon. Most of them are filled with sediments and allow us to identify two channel fill type seismic units.

- The first generation corresponds to the channel fill unit ch1. It is detected across both the Dumbéa and Boulari systems. The channel flanks widen with a moderate slope gradient $(8 \%$ to 25\%), (Pr88, Fig. 07). Extensions of the masked portions of the channel structures enable us to define the thalweg position and to identify the base of the valleys at depths ranging from 90 to 100 ms (twt). Reflectors suggest a divergent fill showing a progressive thickening through the channel axis, while the channel flank merges with the $\mathrm{R} 2$ reflector.

- The second generation of incised channels includes all four identified channel fill sub-units ch2.1 to ch2.4. Seismic records show that the second generation is locally stacked over the ch1 unit and channels have developed over the entire depth of the structure with thalwegs ranging from 75 to $125 \mathrm{~ms}$ (maximum value along the 5-Miles channel). Channel flanks truncate the R2 reflector and merge laterally with the R3 seismic marker (Fig. 8). As noted previously (Le Roy et al., 2008), most of the incised channels are a few hundred meters wide (less than $500 \mathrm{~m}$ ) and display a $\mathrm{V}$ or 
U-shape with slope gradients of up to $60 \%$. The distinction of the channel fill units is based on the reflective reflectors $\mathrm{R} 4$ and $\mathrm{R} 5$ visible through the distal part of the channel systems and contrast of seismic facies. The reflection configuration of the ch2.1 unit shows a complex fill with a basal part composed of reflective reflectors onlapping the channel flanks (Composite line, Fig. 7). The upper unit ch2.2 is well developed through the channel systems. It shows weak reflectors and a transparent seismic facies with onlap terminations. It is topped by the R4 reflector, interpreted as a ravinement surface (Le Roy et al., 2008), and overlaid by a set of reflectors marking a local slight divergent oblique fill (ch2.3). The uppermost unit ch2.4 lying over the R5 reflector is clearly merging with the sh5.2 unit (Figs 7 and8, Pr 209, Fig. 9).

\subsubsection{Dome type unit (d type)}

This type concerns chaotic facies located at the top of the R2 and R3 reflectors. (Figs. 7 and 8). Two dome type units are depicted: $\mathrm{d} 1$ (deeper) and d2. The dome-shape structures appear relatively narrow, with diameters of about 100 to $400 \mathrm{~m}$, and display a highly fluctuating vertical extension ranging from a few meters to several decametres. Their geometry and location are easy to interpret as coral reefs and patch reefs developed within the lagoon.

\subsection{Coring and chronostratigraphic attributions}

Analysis of new cores focuses on the Boulari System only (Tab. 1 and 2). The recovered lengths of core samples are quite limited and do not exceed $2.5 \mathrm{~m}$, but despite the depth of penetration, they have allowed us to identify upper seismic units and to constrain the chronostratigraphic scheme of the lagoon deposits. Six cores are located along the composite line and depict a strong contrast between the Boulari lagoon depression and the lagoon plateau (Figs. 11 and 12).

In the lagoon depression, the CAL_BAN_29 core was taken in a water depth of $28 \mathrm{~m}$ in the proximal part shows an upper unit (U1LD). These sedimentary deposits are composed of dominant carbonate greyish mud with sandy layers overlying a reddish terrigenous silty-to-sandy unit (U3LD). The two units are separated by a sharp bounding surface. Presence of shell fragments and gastropods within the upper unit (U1LD) attests to a marine depositional setting. In contrast, the red lower unit U3LD is devoid of bioclasts and contains sparse coal debris 
corresponding to terrestrial (paleo-soil) deposits. Locally, an intermediate unit (U2LD) composed of greyish structureless and bioturbated muds with low carbonate content, including numerous organic and charcoal debris, is observed between 40 and $150 \mathrm{~cm}$ below the sea floor (CAL_BAN_C032), and has been interpreted as tidal mudflat deposits.

The AMS ${ }^{14} \mathrm{C}$ ages of the top unit U1LD provided from coal debris range from $10.1 \mathrm{kyr}$ to 8.9 cal kyr B.P. (Figs. 12 and 13) and attest to a continental environment prevailing within the lagoon depression until the Holocene times. The oldest $\mathrm{AMS}{ }^{14} \mathrm{C}$ ages of preserved turitella shells sampled from within the U3LD unit range from 7.6 (CAL_BAN_C016, depth $25 \mathrm{~m}$ ) to 7 cal kyr B.P. (CAL_BAN_C032), and suggest an overall flooding of the lagoon between 8.9 and 7 cal kyr B.P. As a consequence, the tidal mud deposits recovered in the proximal lagoon depression were settled sometime between these two chronological markers. Moreover, the uppermost part of the upper U1LD unit (the top $40 \mathrm{~cm}$ ) shows a progressive grading to reddish muddy facies attesting to an increase of terrigenous input (correlated with a decrease of the Ca content) after $4.1 \mathrm{cal} \mathrm{kyr}$ B.P. (dating obtained on a turitella fragment on CAL_BAN_C029).

The other cores located through the coral plateau are of a sandy nature with a high biogenic carbonate fraction (mostly $>90 \%$ ), including numerous shell fragments, gastropods, foraminifers, and isolated coral pebbles (U1CP unit, Fig.11). This corresponds to reef-flat and back reef derived materials as described in previous studies dealing with surficial lagoon deposits (Castellaro, 1999; Yamano et al., 2000; Dawson et al., 2012). The fine sands are mostly located through the channel infill (CAL BOU_C011, depth $42 \mathrm{~m}$ ) and correspond to the ch2.4 seismic subunit, meanwhile coarser materials are located at the top of the plateau where they are correlated to the sh5 unit. This distribution could be interpreted as a response to transportation by wave energy, which is more developed over shallow domains. Moreover, the coarser layers (allowing the individualization of a sedimentary U2CP unit) include coral pebbles and gravels, and are located at the base of some of the cores (CAL_BOU_C010, CAL_BOU_C012, CAL_BOU_C014) and locally separated from the upper sandy deposits by a silty-clay veneer of about $10 \mathrm{~cm}$, marked as the U1'CP sedimentary unit (CAL_BOU_C014, depth $31 \mathrm{~m})$. The location of coarser layers - the U2CP unit- matches with the R5 reflector separating the sh5.1 and sh5.2 units identified through the coral plateau. The $\mathrm{AMS}{ }^{14} \mathrm{C}$ age of unit $\mathrm{U} 1 \mathrm{CP}$ is $7.8 \mathrm{cal}$ kyr B.P. (CAL_BOU_C010, depth $33 \mathrm{~m}$ ), which suggests that marine conditions could have occurred 
through the coral plateau while continental sedimentation was still active through the lagoon depression.

\subsection{Local distribution and thickness variations.}

Figure 13 displays the cumulative thickness variations of sequences 2 and 3 assumed to correspond to the mean sedimentary infill of the Boulari system. The maximum thicknesses are about $40 \mathrm{~ms}$ TWT (i.e. about 35 to $40 \mathrm{~m}$ ) and are observed across the Boulari lagoon depression, along the channel system and across the Lagoon Plateau. This is quite consistent with the $34 \mathrm{~m}$-thickness of the Upper Pleistocene series recovered in the Amédée 4 Borehole. In contrast, the inner ridge basement terminating the Boulari lagoon depression is nearly devoid of deposits.

\section{Discussion}

\subsection{Dating of seismic units}

The new sediment core data lead us to consider that Holocene deposits correspond to the seismic units located above the R4 reflector (Fig.11). These units have a thickness ranging from 5 to $10 \mathrm{~ms}$ TWT above the coral plateau, i.e. 7 to $15 \mathrm{~m}$ thick. This is consistent with the data provided by the drill cores operated on the lagoon islets of Amédée, located immediately behind the barrier reef near the Boulari pass, but also from the the Maître and Mba islets close to the Nouméa Peninsula (see Fig 3 for location). Indeed, the drill cores reveal that the Holocene unit is 5 to $15 \mathrm{~m}$ thick and that post-glacial reef growth started about around $\sim 7.5-7$ cal kyr B.P. for the fringing reefs and 8.2 cal kyr B.P. for the Amédée Reef (Cabioch et al., 1995, 1996; Andrefouet et al., 2009; Yamano et al., 2014). The Mba islet is assumed to have formed directly over the sediment-infilled lagoon when the sea level rose about $1.1 \mathrm{~m}$ above the present-day level and stabilized from $\sim 6.5$ to $2.8 \mathrm{cal} \mathrm{kyr}$ B.P., before dropping after 2.8 cal kyr B.P. (Yamano et al., 2014). By extension, the base of the last generation of incisions correlated with the R3 reflector could be considered as the basal unconformity contemporaneous to the MIS 2. This implies that the post-glacial and interglacial episodes include the sh4, sh5, d2, and the ch2a to ch2d seismic units. The d1 dome-type seismic unit is thus the expression of the Last Interglacial (MIS5) reef also recovered at a depth of $3 \mathrm{~m}$ below the Holocene reef along the Ricaudy reef at Noumea (Cabioch et al., 1999). Following this observation, we could argue that the first 
generation of incised valleys and the correlated R2 reflector corresponds to the MIS6 sea-level regression, i.e. to the unconformity separating the MIS 5 and MIS 7 reef units recovered in the Amédée 4 borehole (Cabioch et al., 1999). In this way, unit sh4.2 that shows a similar facies to the sh3.2 unit can also be interpreted as corresponding to lowstand terrigenous deposits contemporaneous to the MIS6 sea-level drop.

\subsection{Sequential interpretation}

A previous study by Le Roy et al. (2008) proposed a sequential interpretation of the lagoon deposits with the identification of two major seismic sequences (sequences 2 and 3 ) bounded by type1 erosive surfaces materialized by two generations of channel incisions. However, this interpretation lacked core data and complementary seismic lines through the Boulari lagoon depression. The present work confirms the occurrence of two type-1 seismic sequences corresponding to the last two 100 ka sea-level cycles. A third underlying sequence (sequence 1) is observed at the base of the Boulari lagoon depression but its sedimentary nature remains difficult to interpret (Fig. 10). The rugged form of the R1 reflector could be interpreted as fossilized pinnacle reefs but could also be the expression of an inherited morphology from the Cenozoic formations that outcrop along the coastline. System tracts are only clearly distinguished through the upper sequence and are based on physical surfaces corresponding to the seismic reflectors R4 and R5. In the Boulari lagoon depression, most of the sedimentary infilling (seismic units sh3.2 and sh4.2) is composed of aggrading continental deposits lying above the R3 and R2 sequence boundaries. It constitutes two distinct system tracts made up of continental facies with stacked amalgamated channel fills aggrading through the shelf. They are stacked behind a natural barrier of outcropping basement (elevation of about $20 \mathrm{~m}$, top at $25 \mathrm{mbsl}$ ) preventing their seaward export to the basin floor. Their base corresponds to sequence boundaries, and, as their deposition was possible with available accommodation, they are thus interpreted as early transgressive system tracts (TST) reaching a total thickness of $25 \mathrm{~ms}$ twt (i.e. about 25m). The R4 reflector incising the sh4.2 unit is interpreted as the expression of a ravinement surface developed during a marine flooding of the lagoon. This reflector is very clear on the channel systems of the lagoon plateau and constitutes a major feature that affects the valley-fill succession. As proposed for a typical shelf with buried incised valleys, the sharp narrow geometry of the R4 surface incising the lower deposits is interpreted as the migration of a tidal inlet during sea-level rise (Allen, 1991). In a similar way, the R5 reflector topping the channel fill succession and extending over the irregular upper 
surface of the sh4.2 unit is also considered as a flooding surface. Its wide extent points out the landward retreat of the adjacent bay line across the shelf due to drowning, and its slight erosive character could be interpreted as a wave-induced ravinement surface (Allen, 1991). The maximum flooding surface is not obvious on seismic lines; it could be locally recognized at the base of the bioherms forming a highstand system tract that probably corresponds to the muddy layer recovered in core CAL_BOU_C014 (U1'CP unit, Fig. 11).

Within the valleys, the sh4.1 unit is imaged over the banks of the Boulari system. Its prograding inner reflectors suggest a detrital wedge fed by the erosion of an adjacent emerged relief during an early transgression. In contrast, the high reflective basal reflectors of unit ch2.1 located at the bottom of the incised channels could be interpreted as a lowstand system tract (LST) with a preserved channel lag made up of coarse fluvial sediments. The upper unit ch2.2, located below the R4 ravinement surface, exhibits an aggrading fill with onlapping terminations. It could also be interpreted as a part of an LST or considered as an early TST. In this case, it corresponds to either early transgressive tidal estuarine sand and mud deposits stepping landward and onlapping the alluvial deposits (Allen, 1991), or to « alluvial transgressive deposits » defined in the stratigraphic model of Shanley and McCabe (1993). Finally, units ch2.3 and ch2.4 located above the ravinement surfaces are considered as TST and unit ch2.4 is a possible associated highstand system tract (HST). Both units are clearly correlated to the sh5 units. The last dome unit d2 is also clearly linked to the TST and HST. In most seismic lines, the domes d2 are settled on the top of the channel banks that seem to correspond to the favoured location for their growth. In the deeper part of the 5miles-channel, their aggradation stopped at $-60 \mathrm{~m}$ b.s.l, i.e. after the Younger Dryas (Bard et al., 2010).

\subsection{Age of the lagoon infill}

The morphogenesis of the lagoon including the channel systems does not seem older than the deposits corresponding to the second sequence bounded by the R2 reflector. As a consequence, the first deposits could be considered contemporaneous to the episode preceding the first stage of incision and corresponding to the first sequence located below the R2 marker. Considering that the mean depths of the R1 and R2 reflectors across the lagoon depression are about 70 and $60 \mathrm{~m}$ b.s.l., respectively, and that the subsidence rate affecting the lagoon is about $0.16 \mathrm{~mm} . \mathrm{yr}^{-1}+/-0.04 \mathrm{~mm}$ (similar to the subsidence values obtained for the Amédée islet between the end of MIS5e and the 
early Holocene (Cabioch, 2003; Frank et al., 2006; Yamano et al., 2014), the first significant flooding of the lagoon associated with the deposition of marine deposits is assumed to have started during MIS7, at 220 cal kyr B.P. (Fig. 14).

The new results corroborate the first hypothesis from seismic data and confirm that the age of the lagoon sedimentary fill does not exceed the last three 100 ka sedimentary sequences. Typical coral reef communities recovered along the modern barrier reef are likely to not have occurred prior to 430 cal kyr B.P., during MIS11 (Montaggioni et al., 2011). In western Pacific, climate conditions over the early and mid Pleistocene (pre-MIS11) appear to have been not conducive to luxuriant coral reef development (Russon et al. 2009; Montaggioni et al., 2011) and major reef occurrences of the older Pleistocene reported over the world often exhibit ramp or discontinuous rimmed shelf morphologies (Gischler et al., 2015). In any case, the disparate ages of the lagoon and reefs can be reconciled with the fact that the first reefs were initially fringing structures without a lagoon. This last domain was very limited and restricted to the part of the shelf corresponding to the location of the present day coral plateau. The closure of the lagoon requires $200 \mathrm{ka}$ of subsidence (about $30 \mathrm{~m}$ ), balanced by reef growth in the outer shelf.

\subsection{Mixed regime and sediment preservation}

One of the most significant characteristics of SW NC lagoonal sedimentation is the preservation of thick continental deposits in the Boulari lagoon depression. They consist of stacked prograding-to-aggrading alluvial deposits associated to the early TST of sequences 2 and 3 . The absence of preserved intermediate highstand deposits is assumed to be due to the erosion of the thin marine highstand cover which settled during MIS5 (Fig. 14). The lagoonal depression is isolated from the rest of the shelf by a basement ridge and is quite similar to the present day semi-endoreic basin of "Plaine des Lacs" $\left(22^{\circ} 09^{\prime} 03^{\prime \prime} \mathrm{S}, 166^{\circ} 47^{\prime} 55^{\prime \prime} \mathrm{N}\right)$ located 200 to $300 \mathrm{~m}$ above sea-level in the southern peridotite massif of Grande Terre (Chevillote et al., 2005; Chardon and Chevillote, 2006). At a small scale, it is also comparable to the Plum swamp $\left(22^{\circ} 18^{\prime} 0^{\prime \prime} \mathrm{S}, 166^{\circ} 40^{\prime} 11^{\prime \prime} \mathrm{)}\right)$ located along the Plum River at $10 \mathrm{~m}$ above s.l, in the vicinity of Mont D'or. Seismic records show that the upstream part of the lagoon paleo-drainage network ends through the Boulari lagoon depression and does not show any direct connection with present-day continental rivers. Thus, even if a portion of the terrigenous sediments was exported to the deep basin during lowstand incision as suggested by the channel lag 
deposits, the depression acts as a buffer zone and allows the preservation of a significant fraction of clastics during episodes of shelf emersion and progressive flooding (Fig. 15). The submersion of the top of the basement ridge located at $-40 \mathrm{mbsl}$ at present day has probably partly controlled the shift from continental to marine deposits during the last post glacial and MIS5 sea level transgression events. Nevertheless, the cores collected across the Boulari lagoon depression also reveal that part of the clastics remain significant during flooding and highstands with the deposition of silts and clay sediments containing less than $40 \%$ carbonates. This is confirmed by analyses of modern surficial deposits of the Boulari lagoon depression composed of 40 to $80 \%$ muddy materials (Ouillon et al., 2010).

In contrast, the lagoon plateau corresponds to a representative carbonate shelf with sand prone deposits derived from reef-flat and back reef domains. Deposits are mainly aggrading and mostly associated to TST. Reef prograding geometries are locally observed along the channel banks and are considered as preserved regressive deposits, although their nature remains unconstrained. Outside the channel network, lowstand stages correspond to sedimentary hiatuses and unconformities. The lagoon is thus characterized by a strong spatial sedimentary segregation between clastics and carbonates with no significant variations related to $100 \mathrm{ka}\left(4^{\text {th }}\right.$ order) sea-level fluctuations. Moreover, the subsidence of the lagoon offers accommodation for sedimentation and prevents rapid infilling. Its semi-filled character can be considered as a mature reef lagoon and differs from the "bucket fill" geometry mentioned for infilled lagoons (or "senile reefs" (Ladd, 1950; Hopley, 1982; Tudhope, 1989; Harris et al., 2015). The semi-filled geometry could also be promoted by numerous channels persisting during highstands that may accommodate the evacuation of sediment mobilized in the lagoon during storm events. This mechanism is invoked for the Polynesian Tahaa reef lagoon (Toomey et al., 2016) in NC. Indeed, core CAL_BOU_C011, collected in the upper unit of channel fill, displays a uniform fine sand which differs from the medium to coarse sand recovered at the top of the adjoining reef plateau. Thus, winnowing of the fine sands from the plateau could also be considered, taking into account that the mean annual significant wave height of $2 \mathrm{~m}$ (Young, 1999) or $2.1 \mathrm{~m}$ (Caires et al., 2005; Douillet et al., 2001) given for the lagoon is able to remobilize 
sediments in shallow parts of the lagoon. Local channels with minimal sediment accumulation, such as in the Boulari system, suggest a similar sediment transfer to the deep basin. Furthermore, we can also suggest that during highstands the mean bottom of the lagoon could maintain a water depth of around $20 \mathrm{~m}$, as today, within the bathymetry range of hydrodynamics (tidal currents, waves). Considering the variations of relative sea-level and a mean water depth in the lagoon of about $20 \mathrm{~m}$ during the last $220 \mathrm{ka}$, its evolution was associated to the continental environment during $70 \%$ of the time. It is thus not surprising to find this continental imprint in the sediment record.

\subsection{Incision network}

It is noticeable that the amplitude (horizontal and vertical) of incisions increases with time through the lagoon. In the lagoon depression and the proximal part of the carbonate plateau (Figs. 7 and 8), the first generation of incisions (R2) is low (5 m maximum of depth) or absent. In contrast, the second generation of incisions corresponding to the MIS 2 sea-level fall is well expressed, with vertical depths reaching 12 to $15 \mathrm{~m}$ in the same domains. In most parts of the carbonate plateau, the $\mathrm{R} 3$ incision obliterates the R2 incisions and reaches more than $80 \mathrm{~m}$ at the reef passes. This evolution can be explained by a progressive regressive erosion process that became wider through the proximal lagoon domain during the successive MIS6 and MIS 2 sea level regression events. Even if the interpretation of knick points observed along the incised channels is difficult in regard of variations of the sedimentary thicknesses, their presence coeval with perched fossilized meanders visible on both flanks of the Boulari channel system lead to consider that channels incision was mainly controlled by stream power of rivers during lowstand. It could have been locally enhanced by meteoric downwearing of carbonates but the incised channels could be referred first as a "detachment limited system " (Whipple and Tucker, 2002). As developed in §5.4, tidal dynamics have also controlled the evolution of channel systems but it only occurred during last stages of sedimentary infill. A similar evolution is assumed for the different channel systems of the SW NC lagoon even if local geomorpohlogic variations occur during incisions. Along the Boulari system, the widening of the downstream channel, not observed in the Dumbea system, suggests that the channel has spread in 
front of the emerged barrier reef during the MIS 2 sea-level fall before incising the outer shelf. Modern reefs have accreted above the top of the channel flanks and some small patches interpreted as coral bioherms are also identified on the channel bars and stepped meanders (Fig. 5b).

Finally, the wide platform front of the Boulari system has prevented the establishment of a continuous connection between regressive incisions and the fluvial channels on land. In other parts of the islands, these connections were likely established in numerous places where the platform is narrower.

\subsection{Holocene flooding and sedimentation}

AMS radiocarbon dating (as shown in core Cal_BOU_16) suggests that terrigenous deposits lasted through the Boulari lagoon depression at least until 8.9 cal kyr B.P. at a water depth of $27 \mathrm{~m}$. Marine flooding of the Boulari lagoon depression is assumed to have occurred soon after this date. In the deeper part of the lagoon, dating provided from core CAL_BOU_29 shows that marine flooding has reached $-35 \mathrm{mbsl}$ prior to $7.8 \mathrm{cal}$ kyr B.P. This is consistent with the sea-level curve computed for the Vanuatu Islands after correction of local tectonic uplift rate of $\sim 3 \mathrm{~mm} \mathrm{yr}^{-1}$ for the last $23 \mathrm{kyr}$ (Cabioch et al., 2003). Furthermore, previous works have revealed that reef growth started late in the postglacial period, at about 7.5 to 7 cal kyr B.P. for the fringing reefs and 8.2 cal kyr B.P. for the Amédée Reef (Cabioch et al., 1995, 1996). Together, these data lead us to consider that the complete flooding of the SW NC lagoon occurred at about 7.5 cal kyr B.P., with dominant terrigenous sedimentation in the Boulari lagoon depression during the initial flooding of the deeper channel parts (i.e. $-80 \mathrm{~m}$ b.s.l at about 13 cal kyr B.P.).

Sedimentation rates computed from the Holocene marine deposits collected along the Boulari system are low, with some disparities. In the mid-shelf, core CAL_BOU_C026 gives an average of $0.25 \mathrm{~mm} / \mathrm{yr}$, meanwhile values are about $0.13 \mathrm{~mm} / \mathrm{yr}$ for core CAL_BAN_C016 located in the Boulari lagoon depression. Values are much lower than the rates of $3 \mathrm{~mm} / \mathrm{yr}$ given by Ambatsian et 
al. (1997) for the SW NC lagoon, and $0.5 \mathrm{~mm} / \mathrm{yr}$ by Launay (1972) for the enclosed Bay of Dumbea. Nevertheless, subsidence rates are of the same order of magnitude for the relative steady state of a semi-filled lagoon. This also means that Holocene marine sediment cover does not exceed $2 \mathrm{~m}$ in the largest part of the lagoon, and in many places bathymetry has preserved the inherited morphogenesis acquired during the MIS 2 lowstand or early deglacial sea-level rise. The anastomosed channels and spit bars identified along upstream channel networks (see §4.1) are also described in estuary environments where ebb-dominated point bars are detached from the channel by flood barbs (Dalrymple et al., 2012; Dalrymple et al., 2012; Ginsberg and Aliotta, 2011). . Moreover, the elongated depressions observed in the lagoon suggest an evolution from paleo-channel meanders. They are interpreted as reminiscent of pond basins described along present-day tidal dominated carbonate coast plains and formed by abandoned meanders (Pratt et al., 1992; Dalrymple, 1992). This suggests that tidal dynamics have controlled the later evolution of the Boulari and Dumbea channel networks during the last deglacial sea level rise and could then be preserved on the presentday seafloor

In addition, a recent study of a vegetated sand cay, the Mba islet, located on the platform reefs in the SW NC lagoon, has revealed that it was formed around 6.5 to 2.8 cal kyr B.P., when sea level was stabilized $\sim 1.1 \mathrm{~m}$ higher than at present (Yamano et al., 2014). The presence of domes located in the Boulari lagoon depression (see §4.1) could have been contemporaneous to this maximum highstand episode. They correspond to bioherms made of oysters and scleractinian corals (Laboute, 1988; Borsa et al., 2010). A mud layer buries the bioherms, which confirms that they correspond to fossilized structures. Furthermore, the transition of marine greyish mud with sandy layers to reddish terrigenous silty to sandy deposits at the top of the Boulari lagoon depression (dated after $4.1 \mathrm{cal}$ kyr B.P.), could be linked to the Holocene sea-level fall and/or to the coeval change in the coastal plain as shown by Stevenson (2004), who noticed a decline in mangrove pollen after 3 cal kyr B.P. in presentday coastal swamps.

\subsection{Inherited morphologic and structural control}


The SW NC lagoon represents an example of a very shallow rimmed shelf. It is bounded by a very steep slope and corresponds to an "escarpment margin" type of carbonate platform (Emery, 1996). This morphology induces a reduction of barrier reef progradation because it could not have developed over the steep slope, as a consequence the platform facies are mainly built vertically, while the mean depth of the lagoon is about $20 \mathrm{~m}$. From the $226 \mathrm{~m}$-long core drilled on the Ténia islet (Core Ténia 1), it was proven that the SW NC carbonate shelf overlays chert (phtanitic) Eocene age bed-rock that outcrops on land along the coast and on some lagoon islets (Coudray, 1976). In the Amédée 4 core, located at the mouth of the Boulari system, the Pleistocene carbonate substrate was reached at $126.50 \mathrm{~m}$ deep and corresponds to Poya nappe, i.e. Upper Cretaceous to Eocene oceanic basalts (Cabioch et al., 1999). Furthermore, this bedrock is bounded by major N130/150 ${ }^{\circ} \mathrm{E}$ trending faults along the continental slope, related to Miocene extensional faulting that individualized tilted blocks along the NC ridge (Dugas and Debenay, 1980, 1981; Flamand, 2006; Lagabrielle et al., 2005; Chardon et al., 2008; Collot et al., 2008). Some other extensional segments of the vertical faults are also assumed to control the morphological organization of NE-SW trending inner ridges surrounded by reef patch complexes along the SW NC lagoon, and the general morphology of mean paleo-valleys is most likely controlled by the structural framework of the NC basement (Lagabrielle et al., 2005; Le Roy et al., 2008). As shown by the Dumbéa upstream drainage system developed between Pleistocene patch reefs, it is also clear that the development of the drainage system was drastically constrained by the paleo-morphology of the emerged Last Interglacial coral reefs during the Last Glacial Maximum lowstand. It also underlines the control of lagoon morphology by the inherited paleo-network from one glacial-interglacial cycle to another.

In contrast, the morphology and structure of the south-eastern margin of Grande Terre show significant differences (Fig. 16): the eastern lagoon is narrower (5 to $10 \mathrm{~km}$ ) and deeper (mean water depth is $40 \mathrm{~m}$ ) and is bounded by a discontinuous drowned barrier reef whose crest remains in subtidal settings with water depths of about $20 \mathrm{~m}$ (Flamand, 2006). The adjacent slope is much less steeper than the western margin, with a gradient equal to or even lower than $1^{\circ}$. It delineates a large 
"glacis" divided into two stepped levels separated by a slope break: the upper glacis extending from 80 to $450 \mathrm{~m}$, and the lower one in a deeper position. The eastern coast of NC corresponds to the windward coast exposed to the south-easterly $\left(110^{\circ}\right)$ trade winds (Ouillon et al., 2010 ) and should be characterized by a shallow, well developed reef edifice as described in the classical model for reef growth (Hopley, 1982; James, 1983). Moreover, as shown by the recent study of the Great Bahamas Bank (Purkis and Harris, 2016), areas of filled accommodation mostly extend along the windward margin of the GBB, which is not observed on the drowned eastern NC lagoon, itself appearing rather conformable to an empty bucket pattern (Ladd, 1950; Harris et al., 2015).

Thus, factors that have led to the differentiation of reef platforms on both sides of Grande Terre are to be considered differently. Here again, the inherited morphology and structure are the two main attributes that account for the contrast with the western side. Previous seismic records collected across the eastern NC continental margin have shown that the present barrier reef stands at the crest of a carbonate ramp showing several prograding sub-units (Chardon et al., 2008). The latest prograding sub-units of that ramp delineate the functional uppermost slope of the margin that coincides with the 'high glacis'. The 250 to $450 \mathrm{~m}$-thick carbonate ramp is believed to have settled during the Quaternary and developed on the top of an Early Pliocene fluvial-deltaic sedimentary sequence and an Early to mid-Miocene coarse clastic deltaic wedge affected by normal faults. This clastic wedge shows progressive slopes forming the lower part of the morphologic glacis extending to depths of over $1500 \mathrm{~m}$ b.s.l. This bathymetry allowed the progradation of carbonate deposition during the Quaternary and the consecutive ramp edification.

Even if coral and platform growths are also dependent on several factors, including nutrient availability, turbidity, salinity, light availability, and sediment removal, the inherited substratum composed of clastic unconsolidated deposits allows us to explain the deeper lagoon and the interrupted modern barrier reef observed along the northeastern NC margin. 
The gently sloping carbonate ramp maintained a large accommodation space during sea-level rise and could locally have outpaced the carbonate production leading to the drowning of some reef segments (Schlagger, 1992; Emery, 1996). This process could have been enhanced by significant subsidence, higher than at the SW lagoon, but core data are lacking (Flamand, 2006). The detailed survey of the SE NC lagoon infilling is still missing and the possible preservation of terrigenous deposits remains unknown. Nevertheless, paleo-valleys are also well marked, with a network extending parallel to the coast in the proximal part of the lagoon. Channels bend at right angles to reach the pass inlets, indicating a catchment by the main stream flowing outside the lagoon. The first investigation related to episodes of river downcutting and subsequent aggradation could be imputable to the two last glacial cycles over the last two hundred thousand years (Chardon et al., 2008).

The southern margin of Grande Terre, the Corne Sud area, is also characterized by ramp morphology and the absence of barrier reef, probably due to tectonic subsidence and recent faulting along the Havannah channel bounding the southern extremity of Grande Terre (Le Roy et al., 2008). Our results confirm the evidence of a fault zone extending to the end of the Havanah channel which cuts the "5-miles" channel system (Fig.6). The numerous downstream meandering fossilized channels seem to have stagnated and spread along tilted blocks bounded by the fault corridor. As suggested by Cabioch (1988), the growth of the southern margin carbonate platform is thus linked to the subsidence of a southward tilted block.

\subsection{Comparison with other modern mixed platforms}

As mentioned in the introduction, modern mixed platforms are relatively common at low latitudes. Most of the recent related publications have focused on the northeast Australian Great Barrier Reef (GBR) (Johnson et al., 1982; Belperio, 1983; Johnson and Searle, 1984; Larcombe and Carter, 1998; Woolfe et al., 1998; Abbey et al., 2011; Lewis, 2001; Fiedling et al., 2003; Webtser et al., 2011; Hinestrosa et al., 2014). The GBR is the largest example of a tropical mixed 
siliciclastic/carbonate system, with a bigger and deeper lagoon than NC. The occurrence of terrigenous content in sediment of the GBR inner shelves and the presence of incised channels in the lagoon are probably two of the most significant similarities with the NC lagoon margins.

The terrigenous content in GBR sediments is located at the seafloor along the inner shelf of the lagoon and decreases seaward. Nevertheless, it is preserved across most of the shelf below surficial deposits (Belperio, 1983). Geophysical and borehole data from the inner shelves of the Central GBR shelf have recovered 1 to $2 \mathrm{~m}$ of Holocene shallow-bay marine sediments resting on thin basal transgressive mangrove deposits, pre-Holocene terrestrial soils, and 1 to $10 \mathrm{~m}$ thick alluvial deposits overlying a weathered granite bedrock (Maxwell, 1968). The shallow marine sediments are capped by a layer 50 to $70 \mathrm{~cm}$ thick of terrigenous bay mud corresponding to the post $5.5 \mathrm{kyr}$ B.P. HST (Larcombe and Carter; 1998).

A network of incised channels, restricted to the distal part of the outer GBR lagoon, developed in response to the last sea-level regression. Woolfe et al. (1998) concluded that lowstand rivers do not always need to incise the shelf in response to the sea-level fall and the biggest part of the Australian lagoon is an aggradational coastal plain cut by numerous stacked meandering channels. Our results in the SW NC lagoon also demonstrate that rivers did not incise the inner shelf where alluvial deposits aggraded in the lagoons semi-endorheic depression, but incisions were developed at the outlet of the lagoon, as shown on seismic profiles. Furthermore, sedimentary fill of the paleo-channel network of the NC lagoon is symmetrical, indicating a vertical aggradation such as in most cases across the GBR shelf where channels were passively backfilled during the last transgression (Fiedling et al., 2003).

Finally, a significant amount of terrigenous sediments are assumed to have been exported to the GBR slope during the early stages of the postglacial transgression (Fiedling et al., 2003). This point is difficult to verify on the NC margin but siliciclastic transfers to the deep basin were obviously very limited during lowstands when material was trapped nearshore. They could have been reactivated during the early transgression when carried terrigenous deposits spread over proximal lagoon where 
storm events are currently able to disperse fine grain materials during the present highstand. A similar flushing of fine mixed sediments is also cited for the Polynesia Tahaa lagoon to maintain a limited lagoon infiling (Toomey et al., 2016).

In theAtlantic, previous studies of the Brazilian Abrolhos shelf in Brazil (D'Agostini et al., 2015) and the Mayotte lagoon in the SW Indian Ocean (Zinke et al., 2001, 2003a, 2003b) have shown that lagoonal sedimentation is mainly composed of two sets of Pleistocene and Pleistocene-Holocene seismic sequences, such as in NC. In the same way, a subaerial unconformity formed by subaerial exposure during the last glacial maximum separates the two sequences of the Abrholhos shelf, and numerous incisions are reported along the bounding surface (D'Agostini et al., 2015). Nevertheless, this last mixed system responded differently to sea level fluctuations: carbonate sedimentation predominated within the last postglacial transgressive phase. Conversely, the subsequent regressive phase was dominated by nearshore siliciclastic sedimentation restricted to shallow depths. Finally, another significant point highlighted by the study of the Abrholos shelf concerns the control of inherited morphology on lagoon morphology. The spatial seismic data indicate that Holocene nearshore coral reef growth was influenced by the positive antecedent relief of a Pleistocene reef platform and terrigenous sedimentation. This point is also verified for the Belize lagoon where a feedback mechanism between tectonics, reefal buildups, and incised-valley location controls the mixed carbonate-siliciclastic shelf (Choi and Homes, 1982; Esker et al., 1998; Purdy et al., 1998; McNeill et al., 2010; Gischler et al., 2010, Gischler, 2015). First incised-valleys and buildups were tectonically (faults and folds) influenced (allocyclic). During the following four depositional (sea level) events, tectonic influence waned, and subsequent valleys and buildups interacted (autocyclic) to reoccupy their respective positions (Esker et al., 1998; McNeill and al., 2010). Such a system could be transposed to the mixed SW NC shelf. Finally, even if comparison with older systems preserved in the rock record is off topics of this paper focused on modern systems, it could be noticed that study of the mixed neogene carbonate-siliciclastic system in the Gulf of Papua (Papua New Guinea) also 
pointed out that troughs and ridges of the platform influenced the distribution of carbonate occurrences and guided the invasion of siliciclastics (Tcherepanov et al., 2008).

\section{Conclusions}

Several significant points are outlined from this study and complete the previous work devoted to the evolution of modern carbonate rimmed shelves:

-New results provided from the modern evolution of the SW NC mixed shelf show that it has not recorded reciprocal sedimentation during glacial-interglacial sea level cycles, but instead displays a unique or mixed regime. Strong contrasts are observed and depend above all on the two outer lagoon domains: the coral plateau and the lagoon depression corresponding to a semi-closed proximal basin separated from the plateau by a basement ridge.

In the depression, the progressive flooding of the lagoon allowed the deposition of thick aggrading alluvial deposits associated to the early TST. Lowstand terrigenous deposits expected in the first study are probably very limited and preserved and not documented. However, during final flooding and highstands, clastics remain significant, with the deposition of silts and clay sediment containing less than $40 \%$ carbonates. This mixed regime was again interrupted after the last 4 kyr when new terrigenous deposits made of red mud spread over the proximal lagoon.

Across the coral plateau the carbonate sedimentation continued through time and developed mainly during transgressive stages; no terrigenous deposition occurred through this domain except in the channel lag of the paleo-valleys.

-This spatial contrast between terrigenous and carbonate deposits was maintained during sea level cycles. Thus, even if spatial segregation is also observed for other examples of mixed shelves, the SW NC shelf appears to be unique in comparison to the other mixed systems and the conceptual model of reciprocal sedimentation. The presence of a semi-enclosed lagoon depression allows the preservation of a larger volume of terrigenous deposits. 
-The semi-filled geometry of the lagoon is assumed to be the result of the conjunction of several factors: a significant subsidence that offers accommodation for aggrading deposits, the evacuation of sediments mobilized during storm events by channels, the tidal currents, and fair-weather wave dynamics.

-The inherited morphologic conditions and structures may explain the morphologic evolution of the SW NC shelf and its differences with the opposite SE NC shelf. The SW NC shelf is an "escarpment margin" type of carbonate rimmed shelf that developed above a faulted rocky basement, while the deeper SE NC shelf is composed of a carbonate ramp settled over a clastic wedge. Within the SW NC shelf, as proposed for the mixed shelf of Belize, a feedback mechanism between tectonics, reefal buildups, and incised-valley location controls the mixed carbonate-siliciclastic structure during successive glacial interglacial cycles.

\section{Aknowledgments}

This survey was jointly conducted by the French Research Institute for Exploitation of the Sea (IFREMER) and the European Institute for Marine Studies (IUEM, University of Brest) with the collaboration and help of INSU (Institut National des Sciences de I'Univers), the CEREGE (European Institute for the Environment Sciences), TOTAL, the New Caledonian Geological Office (SGNC), and IRD (Research Institute for Development). This work was enabled thanks to the support of the Laboratoire d'Excellence LabexMer (ANR-10-LABX-19-01) and a grant from the French government under the program "Investissements d'Avenir". The authors are grateful to Captain Jean-François Barazer, and the officers and crew members of the R/V ALIS (IRD/Genavir). We would like to thank our CEREGE, IFREMER, IUEM and IRD colleagues for their assistance in all of the surveys, particularly Gilbert Camoin, Sandrine Cheron, Delphine Boissier, and Christophe Prunier. We are also grateful to Katalin Kovacs for the improvement of the English version (Services de Relecture Scientifique, astronogirl@gmail.com). Finally, the authors are very grateful to the reviewers Hayley Cawthra and two anonymous reviewers for their careful examination of previous version of this paper and for their helpful comments

\section{References}

Abbey, E., Webster, J.M, Beaman, R.J., 2011. Geomorphology of submerged reefs on the shelf edge of the Great Barrier Reef: the influence of oscillating Pleistocene sea- levels. Marine Geology, 288, $61-78$. 
Allen, G.P., 1991. Sedimentary processes and facies in the Gironde Estuary : a recent model for macrotidal estuarine systems. In : Rahmani, R.A., Smith, D.G., Reinson, G.E., Zaitlan, B.A. (Eds.), Clastic Tidal Sedimentology. Memoir of the Canadian Society of Petroleum Geologists, Calgary, 16, pp. 29-40.

Ambatsian, P., Fernex, F., Bernat, M., Parron, C. , Lecolle, J., 1997. High metal inputsto closed seas: the New-Caledonian Lagoon. Journal of Geochemical Exploration . 59,59 -74.

Andrefouët, S., Chagnaud, N., Chauvin, C. 2008. Atlas of French overseas coral reefs. Centre IRD de Nouméa, 153 pp.

Andrefouët, S., Cabioch, G., Flamand, B., Pelletier, B., 2009. A reappraisal of the diversity of geomorphological and genetic processes of New Caledonian coral reefs: a synthesis from optical remote sensing, coring and acoustic multibeam observations. Coral Reefs, 28, 691-707.

Anselmetti, F.S., Eberli, G.P. 1997. Sonic velocity in carbonate sediments and rocks, in : Marfurt, J., Palaz, A. (Eds.), Carbonate seismology:SEG Geophysical Developments Series, 6, pp. 53-74.

Avias, J., 1959. Les récifs coralliens de la Nouvelle-Calédonie et quelques-uns de leurs problèmes. Bull. Soc. Geol. Fr. I(7), 424-430.

Avias, J., Coudray, J., 1967. Premiers enseignements apportés par un forage réalisé dans le récif barrière de la Nouvelle-Calédonie. C. R. Acad. Sci. 265, 1867-1869.

Bard, E., Hamelin, B., Delanghe-Sabatier, D., 2010. Deglacial Meltwater Pulse 1B and Younger Dryas Sea Levels Revisited with Boreholes at Tahiti. Science 327, 1235-1237.

Belperio, A.P., 1983. Terrigenous sedimentation in the central Great Barrier Reef lagoon: a model from the Burdekin region. Journal Australian Geol. Geophys., 8, 179-190.

Borsa P., Folcher E., Gilbert, A., 2010. Stalked and fleshy life forms photographed on Banc Gail (southwestern lagoon, New Caledonia), a site heavily impacted by hypersedimentation. InMery P. (ed.) Proceedings of the 11th Pacific Science Inter-Congress, Tahiti, French Polynesia, 2-6 March, 2009.

Cabioch, G., 1988. Récifs frangeants de Nouvelle-Calédonie (Pacifique sud-ouest). Structure interne et influences de l'eustatisme et de la néotectonique. Thèse Doct. Univ. Provence, Publ. Univ. Aix-Marseillel, 291 pp.

Cabioch, G., 2003. Postglacial reef development in the South-West Pacific: case studies from New Caledonia and Vanuatu. Sediment. Geol., 159, 43-59.

Cabioch, G., Banks-Culter, K.A., Beck, W.J., Burr, G.S., Corrège, T., Lawrence Edwards, R., Taylor, F.W., 2003. Continuous reef growth during the last 23 cal kyr BP in a tectonically active zone (Vanuatu, Southwest Pacific). Quaternary Sci. Rev., 22, 1771-1786.

Cabioch, G., Montaggioni, L.F., Faure, G., 1995. Holocene initiation and development of New Caledonian fringing reefs, SW Pacific. Coral Reefs, 14, 131-140.

Cabioch, G., Recy, J., Jouannic, C., Turpin, L., 1996. Contrôle climatique et tectonique de l'édification récifale en Nouvelle-Calédonie au cours du Quaternaire terminal. Bull. Soc. Géol. Fr., 167, 6, 729-742.

Cabioch, G., Taylor, F.W., Reéy, J., Edwards, L.R., Gay, S.C., Faure, G., Burrand, S., Corrège, T. C, 1998. Environmental and tectonic influences on growth and internal structure of a fringing reef at 
Tasmaloum (SW Espiritu Santo, New Hebrides Island Arc, SW Pacific), in G. Camoin, G. and P. J. Calmant, S., Pelletier, B., Lebellegard, P., 2003. New insights on the tectonics along the New Hebrides subduction zone based on GPS results. J. Geophys. Res. 108 (B6), 2319-2340.

Davies (eds), Reefs and carbonate platforms in the Pacific and Indian Oceans, International Association of Sedimentologists, Special Publication 25, pp. 261-277.

Cabioch, G., Corrège, T., Turpin, L., Castellaro, C., Récy, J., 1999. Development patterns of fringing and barrier reefs in New Caledonia (south-west Pacific). Oceanologica Acta 22, 567-578.

Caires, S., Sterl, A., Komen, G., Swail, V., 2005. The KNMI/ERA 40Wave Atlas derived from 45-years of ECMWF reanalysis data. Available at http://www.knmi.nl/waveatlas.

Castellaro, C., 1999. Reconstructions paléoclimatiques et paléoenvironmentales a l'Holocene et au Pléistocene terminal en Nouvelle-Calédonie et aux Seychelles : I'entregistrement par les coraux. PhD Thesis University of Provence, Marseille, 212 pp.

Catuneanu, O. , Galloway, W.E., Kendall , C. G. St. C. , Miall A. D. , Posamentier, H.W. , Strasser , A., Tucker, M.E., 2011. Sequence Stratigraphy: Methodology and Nomenclature. Newsletters on Stratigraphy, 44/3, 173-245.

Chardon, D., Austin, J.A. Jr., Cabioch, G. , Pelletier, B., Saustrup, S., Sage, F., 2008. Tectonics Neogene history of the northeastern New Caledonia continental margin from multichannel reflection seismic profiles. C. R. Geoscience, 340, 68-73.

Chardon, D.,, Chevillotte, V., 2006. Morphotectonic evolution of the New Caledonia ridge (Pacific Southwest) from post-obduction tectonosedimentary record. Tectonophysics , 420, 473-491.

Chevillotte, V., Douillet, P., Cabioch, G., Lafoy, Y., Lagabrielle, Y.,, Maurizot, P., 2005. Evolution géomorphologiques de l'avant-pays du Sud-Ouest de la Nouvelle-Calédonie durant les derniers cycles glaciaires. C. R. Geoscience 337, 695-701.

Choi, D.R., Holmes, C.W., 1982. Foundations of Quaternary reefs in south-central Belize Lagoon, Central America. AAPG Bull., 66, 2663-2671

Collot, J., L. Géli, Y. Lafoy, R. Vially, D. Cluzel, F. Klingelhöefer, Nouzé, H., 2008. Tectonic history of northern New Caledonia Basin from deep offshore seismic reflection: Relation to late Eocene obduction in New Caledonia, southwest Pacific, Tectonics, 27

Coudray, J., 1976. Recherches sur le Neogene et le Quaternaire marins de la Nouvelle-Calédonie; contribution de l'étude sédimentologique a la connaissance de l'histoire géologique post-Eocene. In : Fond. Singer-Polignac (Eds.), Expédition française sur les récifs Nouvelle-Calédonie, Paris, 8, pp. 1276.

D’Agostini, D.P., Cardoso Bastos, A., Tadeu Dos Reis, A., 2015. Modern mixed Carbonate-siliclastic Abrolhos shelf : implications for a mixed depositional model. Journal of Sedimentary Research, 2015, 85, 124-139.

Dalrymple, R.W., Zaitlin, B.A., Boyd, R., 1992. Estuarine facies models: conceptual basis and stratigraphic implications. J Sediment. Petrol., 62, 1130-1146

Dalrymple, R.W., Mackay, D.A., Ichaso, A.A., Choi, K.S., 2012. Processes, Morphodynamics, and Facies of Tide-Dominated Estuaries. In : Davis, Jr., R.A., Dalrymple, R.W. (eds.), Principles of Tidal Sedimentology, Springer Science+Business Media B.V., pp. 79-108. 
Dawson, J.L., Hua. Q.,,cSmithers, S.G., 2012. Benthic foraminifera: Their importance to future reef island resilience. Proc12 ${ }^{\text {th }}$ Int Coral Reef Symp 1:1-7

Debenay, J.P., 1987. Sedimentology in the Southwestern Lagoon of New Caledonia, SW Pacific. J. Coastal Research, 3(1), 77-91.

Douillet, P., Ouillon, S., Cordier, E., 2001. A numerical model for fine suspended sediment transport in the southwest lagoon of New Caledonia. Coral Reefs, 20, 361-372

Doyle, L.J., Roberts, H.H. (eds.) 1988. Carbonate-Clastic Transitions.- Elsevier, Amsterdam, Developments in Sedimentology, 42, 304 p.

Droxler, A., Jorry, S.J., 2013. Deglacial Origin of Barrier Reefs Along Low-Latitude Mixed Siliciclastic and Carbonate Continental Shelf Edges. Annual Review of Marince Science, 5, 165-190

Dugas, F., Debenay, J.P., 1980. Notice explicative de la carte sédimentologique et carte annexe du lagon de Nouvelle-Calédonie à 1/50 000, feuille La Tontouta. ORSTOM, Paris, 44 pp.

Dugas, F., Debenay, J.P., 1981. Notice explicative de la carte sédimentologique et carte annexe du lagon de Nouvelle-Calédonie à 1/50 000, feuille Prony. ORSTOM, Paris, 35 pp.

Dugas, F., Ville, P., Coudray, J., 1980. Etude sismique du lagon sud-ouest de la Nouvelle-Calédonie (Sud-Ouest Pacifique). Paléomorphologies successives et comportement, au Quaternaire supérieur, du littoral de l'île. C. R. Acad. Sc. 290, 963-966.

Dunbar, G.B. , Dickens, G.R., 2003. Late Quaternary shedding of shallow-marine carbonate along a tropical mixed siliciclastic-carbonate shelf: Great Barrier Reef, Australia. Sedimentology, 50 (6), 1061-1077.

Emery, D., 1996. Carbonate Systems. In : Emery, D., Myers, K.J., (Eds.). Sequence Stratigraphy, Blackwell Science Ltd, 211-237.

Esker, D., Eberli, G.P., McNeill, D.F., 1998. The structural ans sedimentologicas controls on the reoccupation of Quaternary incised valleys, Belize Southern Lagoon. AAPG Bulletin, 82, 11, 20752109.

Fielding, C.R., Trueman, J.D., Dickens, G.R., Page, M., 2003, Anatomy of the buried Burdekin River channel across the Great Barrier Reef shelf: How does a major river operate on a tropical mixed siliciclastic/ carbonate margin during sea level lowstand. Sedimentary Geology, 157, 3-4, 291-301

Flamand, B., 2006. Les pentes externes du récif barrière de la Grande Terre de Nouvelle-Calédonie : morphologie, lithologie, contrôle de la tectonique et de l'eustatisme. Phd thesis, University of Bretagne Occidentale (Brest), 240 pp.

Francis, J.M., Dunbar, G.B., Dickens, G.R., Sutherland, I.A., Droxler, A.W., 2007. Siliciclastic sediment across the North Queensland margin (Australia): a Holocene perspective on reciprocal versus coeval deposition in tropical mixedsiliciclastic-carbonate systems. Journal of Sedimentary Research, 77, 572-586.

Frank, N., Turpin, L., Cabioch, G., Blamart, D., Tressens-Fedou, M., Colin, C., Jean-Baptiste, P., 2006. Open system U-series ages of corals from a subsiding reef in New Caledonia : Implications for sea level changes, and subsidence rate. Earth Planet. Sc. Let., 249(3-4), 274-289.

Ginsberg, S. S., Aliotta, S., 2011. Sediment Transport Circulation Pattern through Mesotidal Channels System, in: Ginsberg, S.S. (Ed). Sediment Transport. Croatia, pp. 275-294. 
Gischler, E., 2015. Quaternary reef response to sea-level and environmental change in the western Atlantic. Sedimentology, 64, 429-465.

Gischler, E., Ginsburg, R.N., Herrle, J.O., Prasad, S., 2010. Mixed carbonates and siliciclastics in the Quaternary of southern Belize:Pleistocene turning points in reef development controlled by sea-level change.-Sedimentology, 47, 1049-1068.

Harris, P.M., Purkis, S.J., Ellis, J., Swart, P.K.,, Reijmer, J.J.G., 2015. Mapping water-depth and depositional facies on Great Bahama Bank: Sedimentology, 62, 566-589.

Hinestrosa, G., Webster, J.M., Beaman, R. J., Anderson, L.M., 2014. Seismic stratigraphy and development of the shelf-edge reefs of the Great Barrier Reef, Australia. Marine Geology, 353, 1-20

Hinestrosa, G., Webster, J.M., Beaman, R.J., 2016. Postglacial sediment deposition along a mixed carbonate-siliciclastic margin: new constraints fromthe drowned shelf-edge reefs of the Great barrier reef, Australia Palaeogeogr., Palaeoclimatol., Palaeoecol., 446, 168-185.

Hopley, D., 1982. The geomorphology of the Great Barrier reef:quarternary development of coral reefs. Wiley-Interscience, 453pp.

James, N.P., 1983. Reef environment. In: Scholle, P.A., Bebout,D.G., Moore, C.H. (Eds.), Am. Assoc.Pet. Geol. Mem., vol.33, pp. 346-440.

Johnson, D.P., Searle, D.E., 1984. Post-glacial seismic stratigraphy, central Great Barrier Reef, Australia. Marine Geology, 31, 335-352.

Johnson, D.P., Searle, D.E., Hopley, D., 1982. Positive elief over buried post-glacial channels, Great Barrier Reef Province, Australia. Marine Geology, 46, 149-159.

Laboute, P., 1988. The presence of Scleractinian corals and their means of adapting to a muddy environment: the "Gail Bank". Proceedings, 6th International Coral Reef Symposium, Townsville 3, 107-111.

Ladd, H.S., 1950, Recent reefs, American Association of Petroleum Geologists Bulletin, 34, 203-214.

Lafoy, Y., Auzende, J.M., Smith, R., Labails, C., 2000. Post-Middle Pleistocene geologic evolution of the southern part of the New Caledonian lagoon: Evolution géologique post-Pleistocene moyen du domaine lagonaire néo-calédonien méridional. C. R. Acad. Sc., série IIA - Earth and Planetary Science, 330 (4), 265-272.

Lagabrielle, Y., Maurizot, P., Lafoy, Y., Cabioch, G., Pelletier, B., Regnier, M., Wabete , I., Calmant, S., 2005. Post-Eocene extensional tectonics in Southern New Caledonia (SW Pacific) : Insights from onshore fault analysis and offshore seismic data. Tectonophysics, 403, 1-28.

Larcombe, P., Carter R.M., 1998. Sequence architecture during the Holocene transgression : an example from the Great Barrier Reef shelf, Australia. Sedimentary Geology 117, 97-121

Launay, J., 1972. La sédimentation en Baie de Dumbéa, côte ouest , Nouvelle Calédonie. Cah. ORSTOM (Eds.), Géol. IV(1), 25-51.

Le Roy, P., G. Cabioch, B. Monod, Y. Lagabrielle, B. Pelletier, B. Flamand, 2008. Late Quaternary history of the Noumea lagoon (New Caledonia, Southwestern Pacific) as depicted by seismic stratigraphy and multibeam bathymetry : A modern model of tropical rimmed shelf, Palaeogeography Palaeoclimatology Palaeoecology, 270, 29-45. 
Lewis, A., 2001. Great Barrier Reef Depth and Elevation Model (GBRDEM), Technical Report 33, Townsville, CRC Reef Research Centre. 64 pp.

Maxwell, W.G.H., 1968. Atlas of the Great Barrier Reef, Amsterdam, Elsevier. 250 pp.

McNeill, D.F., Janson, X., Bergman, K.L. , Eberli , G.P., 2010. Belize: A Modern Example of a Mixed Carbonate-Siliciclastic Shelf. H. Westphal et al. (eds.), Carbonate Depositional Systems: Assessing Dimensions and Controlling Parameters, 81-143, DOI 10.1007/978-90-481-9364-6_3.

Mitchum, P J., Vail, P.R., Sangree. J.B., 1977a. Stratigraphic interpretation of seismic relection pattern in depositional sequences. In : Payton C.E., (Ed.), Seismic Stratigraphy, Application to hydrocarbon exploration. Am. Asso. Petrol. Mem., 26, 117-134.

Mitchum, P J., Vail, P.R., 1977b. Seismic stratigraphy and global changes of sea-level, part 7 : stratigraphic interpretation of seismic reflection patterns in depositional sequences. In : Payton C.E., (Ed.), Seismic Stratigraphy, Application to hydrocarbon exploration. Am. Asso. Petrol. Mem., 26, 135144.

Montaggioni, L.F., Cabioch, G., Thouveny, N., Frank, N., Sato, T., Sémah A-M, 2011. Revisiting the Quaternary development history of the western New Caledonian shelf system: From ramp to barrier reef. Marine Geology, 280, 57-75

Mount, J.F., 1984, Mixing of siliciclastic and carbonate sediments in shallow shelf environments: Geology, 12, 432-435.

Ouillon, S., Douillet, P., Lefebvre, J.-P., Le Gendre, R. , Jouon, A. , Bonneton, P., Fernandez, J.-M., Chevillon, C., Magand, O. , Lefèvre, J., Le Hir,, P., Laganier, R., Dumas, F., , Marchesiello, P., Bel Madani, A. , Andrefouet, S., Panche, J.-Y., Fichez. R., 2010. Circulation and suspended sediment transport in a coral reef lagoon: the southwest lagoon of New Caledonia ; New Caledonia Trop. Lagoons Overv. Multidiscip. Investig., 61 (2010), pp. 269-296, 10.1016/j.marpolbul.2010.06.023.

Paris, J.P., 1981. Géologie de la Nouvelle-Calédonie. Mém. BRGM, 133,278 pp.

Payri, C.E., Cabioch, G., 2004. The systematics and significance of coralline red algae in the rhodolith sequence of the Amédée 4 drill core (Southwest New Caledonia). Palaeogeography, Paleoclimatology, Palaeoecology, 204, 187-208.

Posamentier, H.W., Vail, P.R., 1988. Eustatic controls on clastic deposition II-sequence and systems tract models. In : Wilgus, C.K., Hastings, B.S., Kendall, C.G. St. C., Posamentier, H.W., Ross, C.A., Van Wagoner, J.C., (Eds.), Sea Level changes: An Integrated Approach. SEPM Special Publication, Tulsa, $42,125-154$

Purdy, E.G., 1998. Structural termination of the southern end of Belize Barrier Reef. Coral Reefs, 17, 231-234.

Purkis, S.J., Harris, P.M., 2016. The extent and pattern of sediment filling of accommodation space on Great Bahama Bank. Journal of Sedimentary Research, 86, 294-310.

Pratt, B.R., James, N.P., Cowan, C.A., 1992. Peritidal carbonates. In : Walker, R.G., James, N.P (Eds.), Facies Models : Response to sea Level Change, Geological Association of Canada, Geotext1, 303-322.

Reimer, P.J., Bard, E., Bayliss, A., Beck, J.W., Blackwell, P.G., Ramsey, C.B., Grootes, P.M., 2013. IntCal13 and Marine13 radiocarbon age calibration curves 0-50,000 years cal BP. Radiocarbon, 55(4), 1869-1887Rosgen, D.L.1994. A classification of natural rivers. Catena, 22, 3, 169-199. 
Rougerie, F., 1986. Le lagon Sud-Ouest de la Nouvelle-Calédonie : spécificité hydrologique, dynamique et productivité. Etude et thèses, ORSTOM (Eds.), Paris, 234 pp.

Russon, T., Elliot, M., Corrège, Th., De Deckker, P., Cabioch, G., Kisse, C., 2009. Mid/Late Pleistocene paleoceanography of the Coral Sea Region reconstructed from paired $\partial 8 \mathrm{O}-\mathrm{Mg} / \mathrm{Ca}$ measurements. AGU Fall Meeting, Abstracts.

Schalger, W., 1992. Sedimentology and Sequence Stratigraphy of Reefs and Carbonate Platforms. Continuing Education Course Note Series, 34, American Association of Petroleum Geologists.

Schalger, W., Reijmer, J.G., Droxler, A.W., 1994. Highstand Shedding of carbonate platforms.. Journal of Sedimentary Research, 64, 3, 270-281.

Shanley, K.W., McCabe, P.J., Hettinger, R.D., 1993. Tidal influence in Cretaceous fluvial strata from Utah, USA: a key to sequence stratigraphic interpretation. Sedimentology, 39, 905-930.

Stevenson, J., 2004. A late-Holocene record of human impact from the southwest coast of New Caledonia. The Holocene, 14, 6, 888-898.

Stuiver, M., Reimer, P.J, Reimer, R.W., 2013. CALIB 7.0. (WWW program and documentation). URL: http://radiocarbon.pa.qub.ac.uk/calib/calib.html

Tcherepanov, E.N., Droxler, A.W., Lapointe, P., Dickens, G.R., Bentley, S.J., Beaufort, L., Peterson, C., Daniell, J., Opdyke, B.N. 2008. Neogene evolution of the mixed carbonate-siliclastic system in the Gulf of Papua, Papua New Guinea. J. Geophys. Res. 113, F01S21.

Toomey, M.R.,Woodruff, J.D., Donnelly, J.P., Ashton, A.D., Perron, J.T., 2016. Seismic evidence of glacial-age river incision into the Tahaa barrier reef, French Polynesia, Marine Geology, 380, 284-289.

Tudhope, A.W., 1989. Shallowing-upwards sedimentation in a coral reef lagoon, Great Barrier Reef of Australia. Journal Sedimentary Petrology, 59, 1036-1051.

Van Siclen, D.C., 1958, Depositional topography--examples and theory: Am. Assoc.Petroleum Geologists Bull., 42, 8, 1897-1913.

Waelbroeck C., Labeyrie, L., Michel, E., Duplessy, J.C., McManus, J.F., Lambeck, K., Balbon, E., Labracherie, M., 2002. Sea-level and deep water temperature changes derived from benthic foraminifera isotopic records. Quaternary Science Reviews, 21(1-3), 295-305.

Van Wagoner, J.C., Posamentier, H.W., Mitchum, R.M., Vail, P.R., Sarg, J.F., Loutit, T.S., Hardenbol, J., 1988. An overview of sequence stratigraphy and key definitions. In: Wilgus, C.K., Hastings, B.S., Kendall, C.G.St.C., Posamentier, H.W., Ross, C.A., Van Wagoner, J.C. (Eds.), Sea Level Changes-An Integrated Approach, vol. 42. SEPM Special Publication, pp. 39-45.

Walsh, J.P., Nittrouer, C.A., Palinkas, C.M., Ogston, A.S., Sternberg, R.W., Brunskill, G.J., 2004. Clinoform mechanics in the Gulf of Papua, New Guinea. Cont Shelf Res, 24, 2487-2510

Webster, J.M., Yokoyama, Y., Cotterill, C., and Expediton 325, Scientist, 2011. In: I.O.D.P. stratigraphy: Management Inc. (Ed.), Proceedings of the Integrated Ocean Drilling Program, Expedition 325: Great Barrier Reef Environmental Changes (Tokyo).

Whipple, K.X., Tucker, G.E., 2002. Implications of sediment-flux-dependent river incision models for landscape evolution. Journal of Geophysical Research, 107(B2), 2039. 
Wilson, J.L., 1967, Cyclic and reciprocal sedimentation in Virgilian strata of southern New Mexico: Geological Society of America Bulletin, 78, 805-818.

Woolfe, K.J., Larcombe, P., Naish, T.,Purdon, R.G., 1998. Lowstand rivers need not incise the shelf: An example from the Great Barrier Reef, Australia, with implications for sequence stratigraphic models. Geology 26, 75-78.

Yamano, H., Cabioch, G., Chevillon, C., Join, J.L., 2014. Late Holocene sea-level change and reef island evolution in New Caledonia. Geomorphology, 222, 39-45.

Yamano, H., Kayanne, H., Yonekura, N., and Kudo, K., 2000. 21-year changes of backreef coral distribution: causes and significance. Journal of Coastal Research, 16, 99-110.

Young, Y.R., 1999. Seasonal variability of the global ocean wind and wave climate. International Journal of Climatology 19, 931-950.

Zinke J., Reijmer, J.J.G., Thomassin, B.A., 2001. Seismic architecture and sediment distribution within the Holocene barrier reef-lagoon complex of Mayotte (Comoro archipelago, SW Indian Ocean). Paleogeography, Palaeoclimatology, palaeoecology 175, 343-368.

Zinke J., Reijmer, J.J.G., Thomassin, B.A., 2003a. Systems tracts sedimentology in the lagoon of Mayotte associated with the Holocene transgression. Sedimentary Geology 160, 57-79.

Zinke, J., Reijmer, J.J.G., Thomassin, B.A., Dullo, W.-C., Grootes, P.M., Erlenkeuser, H., 2003b. Postglacial flooding history of mayotte Laggon (Comoro Archipelago, southwest Indian Ocean). Marine Geology, 194(3-4), 181-196. 


\section{Figure captions:}

Fig. 1: Location map of New Caledonia and the general setting of the southern part of the main island "Grande Terre" showing the western and eastern shelf margins. Digital Elevation Model from New Caledonian Territory Office. Bo. B. : Boulari Bay, D. B. : Dumbea bay, P. B. : Prony Bay, St-V. B. : Saint Vincent Bay

Fig 2: Location map of the geophysical and coring data set used in this study.

Fig 3: General bathymetry of the Dumbéa, Boulari, and 5-miles channel systems surveyed in this study with lagoon morphologic domains. Geomorphological features of the reef complex are documented from the atlas of French overseas coral reefs (Andrefouët et al., 2008). The values of the background bathymetry is indicated on the figure.

Fig 4: Detailed bathymetry of the Dumbéa channel system characterized by numerous interlaced sinuous channels in the upstream part and a straight geometry of the downstream channel. The values of the background bathymetry is indicated on the figure.

Fig 5: Detailed bathymetry of the Boulari channel with focused extracts of A) the upstream part showing the junction with the lagoon depression and exhibiting bioherm domes (Bang Bay), B) the central part showing a meander with a spit bar and small reef units, C) the downstream part showing stepped terraces. The values of the background bathymetry is indicated on the figure.

Fig 6: Bathymetry of the 5-miles Channel system; A: General view; B: Detailed view south of Ouen Island. The values of the background bathymetry is indicated on the figure.

Fig 7: Representative extracts of sparker seismic lines recorded across the Boulari system and lagoon depression,. Refer to the Figure $10 \mathrm{C}$ for a synthetic view of the stratigraphy.

Fig 8: Representative extracts of sparker seismic lines recorded along the Boulari system. Refer to the Fig. $10 \mathrm{C}$ for a synthetic view of the stratigraphy. 
Fig 9: Representative extracts of sparker seismic lines recorded along the Dumbea system

(A et $B$ ) and the 5-miles channel system (C).

Fig. 10: Synthetic stratigraphy of the Boulari system (A) with sequential interpretation (B) and summary table of seismic stratigraphy of the SW New Caledonian shelf (C).

Fig. 11: Cores collected along the Boulari system with identification of sedimentary units and correlation with seismic data. Results of Ca\% analyses by RX diffractometry are also shown for core

CAL_BAN_CO29.

Fig 12: Core collected across the lagoon depression with AMS radiocarbon ages.

Fig 13: Isopach map in ms (two Way time) of the cumulated sequences 2 and 3 thicknesses.

Fig 14: Synthetic scheme of the Pleistocene lagoon evolution in regard to subsidence and sea level fluctuations. The lagoon depression domain is considered for the sedimentary filling.

Fig.15: Cartoon sketch showing the evolution of the South West New Caledonia lagoon since the Last Glacial Maximum (adapted from Emery, 1996 and Cabioch, 1988).

Fig 16: Synthetic scheme showing the contrast of morphologies and structures between the two

South New-Caledonian shelves. Geology from Coudray (1976), Paris (1981), Cabioch et al. (1999), Chardon et al. (2008).

Table 1: Location and water depths of the cores used in this study

Table 2: Radiocarbon ages for sediment cores collected in the SW New Caledonia lagoon. * radiocarbon ages given in ${ }^{14} \mathrm{C}$ pMC (percent Modern Carbon), corresponding to $1970 \mathrm{AD}$. 


\begin{tabular}{|c|c|c|c|}
\hline Core Label & Latitude (S) & Longitude (E) & $\begin{array}{c}\text { Water } \\
\text { Depth(m) } \\
\text { Below Sea Level }\end{array}$ \\
\hline CAL_BAN_C029 & $22^{\circ} .3378333$ & $166^{\circ} .6878917$ & -28 \\
\hline CAL_BOU_C026 & $22^{\circ} .2834369$ & $166^{\circ} .5336136$ & -22 \\
\hline CAL_BAN_C032 & $22^{\circ} .3827345$ & $166^{\circ} .7320803$ & -28 \\
\hline CAL_BOU_C014 & $22^{\circ} .3753074$ & $166^{\circ} .6000891$ & -31 \\
\hline CAL_BOU_C013 & $22^{\circ} .4131531$ & $166^{\circ} .5516184$ & -38 \\
\hline CAL_BOU_C012 & $22^{\circ} .4016166$ & $166^{\circ} .5790747$ & -32 \\
\hline CAL_BOU_C011 & $22^{\circ} .4511018$ & $166^{\circ} .5524310$ & -42 \\
\hline CAL_BOU_C010 & $22^{\circ} .4590874$ & $166^{\circ} .5385672$ & -33 \\
\hline
\end{tabular}

Table 1 


\begin{tabular}{|c|c|c|c|c|c|c|}
\hline Core Label & $\begin{array}{l}\text { Depth } \\
\text { (cm) }\end{array}$ & Lab. Number & Material & $\begin{array}{l}{ }^{14} \mathrm{C} \text { age } \\
\text { (yr BP) }\end{array}$ & $\begin{array}{l}\text { Error } \\
(1 \sigma)\end{array}$ & $\begin{array}{c}\text { Calendar age } \\
\text { (yr BP, } 2 \sigma \text { ) }\end{array}$ \\
\hline CAL_BOU_C026 & 7,5 & Poz-87292 & gastropod shells & 735 & 30 & 366 \\
\hline CAL_BOU_C026 & 39,5 & Poz-87294 & gastropod shells & 1645 & 30 & 1193 \\
\hline CAL_BOU_C026 & 81,5 & Poz-87295 & gastropod shells & 3485 & 30 & 3349 \\
\hline CAL_BOU_C026 & 103,5 & Poz-63380 & gastropod shells & 4520 & 30 & 4701 \\
\hline CAL_BOU_C029 & 2,5 & BETA-463014 & gastropod shells & $113,3^{*}$ & 0,4 & 43 \\
\hline CAL_BOU_C029 & 10,5 & BETA-463015 & gastropod shells & 3290 & 30 & 3103 \\
\hline CAL_BOU_C029 & 25,5 & BETA-463016 & gastropod shells & 4070 & 30 & 4084 \\
\hline CAL_BOU_C029 & 157,5 & BETA-379657 & wood fragment & 9320 & 40 & 10140 \\
\hline CAL_BOU_C032 & 5,5 & Poz-87289 & gastropod shells & $111,6^{*}$ & 0,33 & 43 \\
\hline CAL_BOU_C032 & 19,5 & Poz-87290 & gastropod shells & 1600 & 40 & 1145 \\
\hline CAL_BOU_C032 & 33,5 & Poz-87291 & gastropod shells & 6530 & 35 & 7028 \\
\hline CAL_BOU_C010 & 159,5 & BETA-379658 & gastropod shells & 7420 & 30 & 7868 \\
\hline
\end{tabular}

Table 2 


\section{Highlights}

- A semi-filled lagoon geometry.

- Differs from general conceptual model of reciprocal sedimentation of mixed sliclastic/carbonate system.

- Strong spatial contrast between clastic inner lagoon depression and outer lagoon coral plateau; 


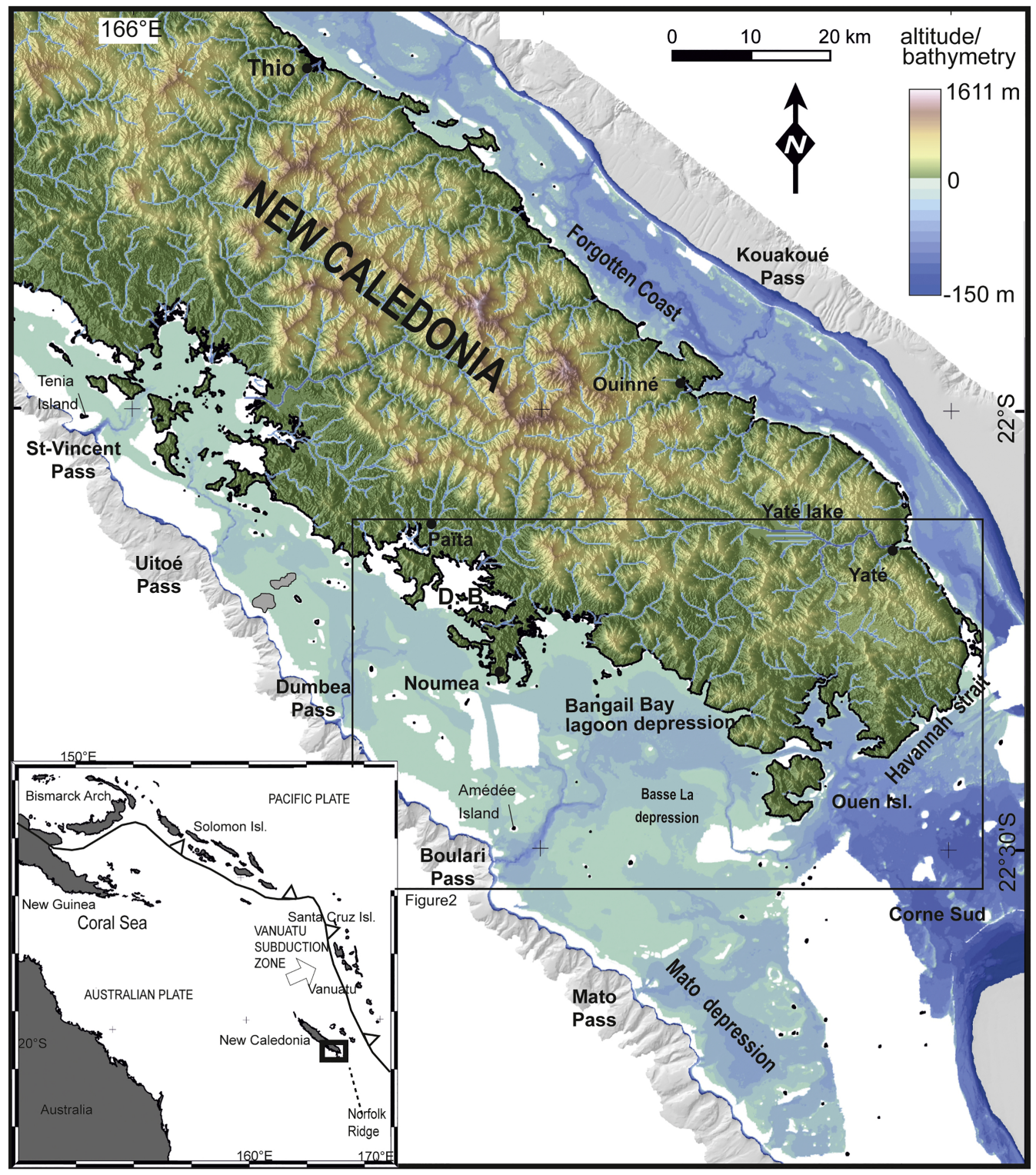

Figure 1 


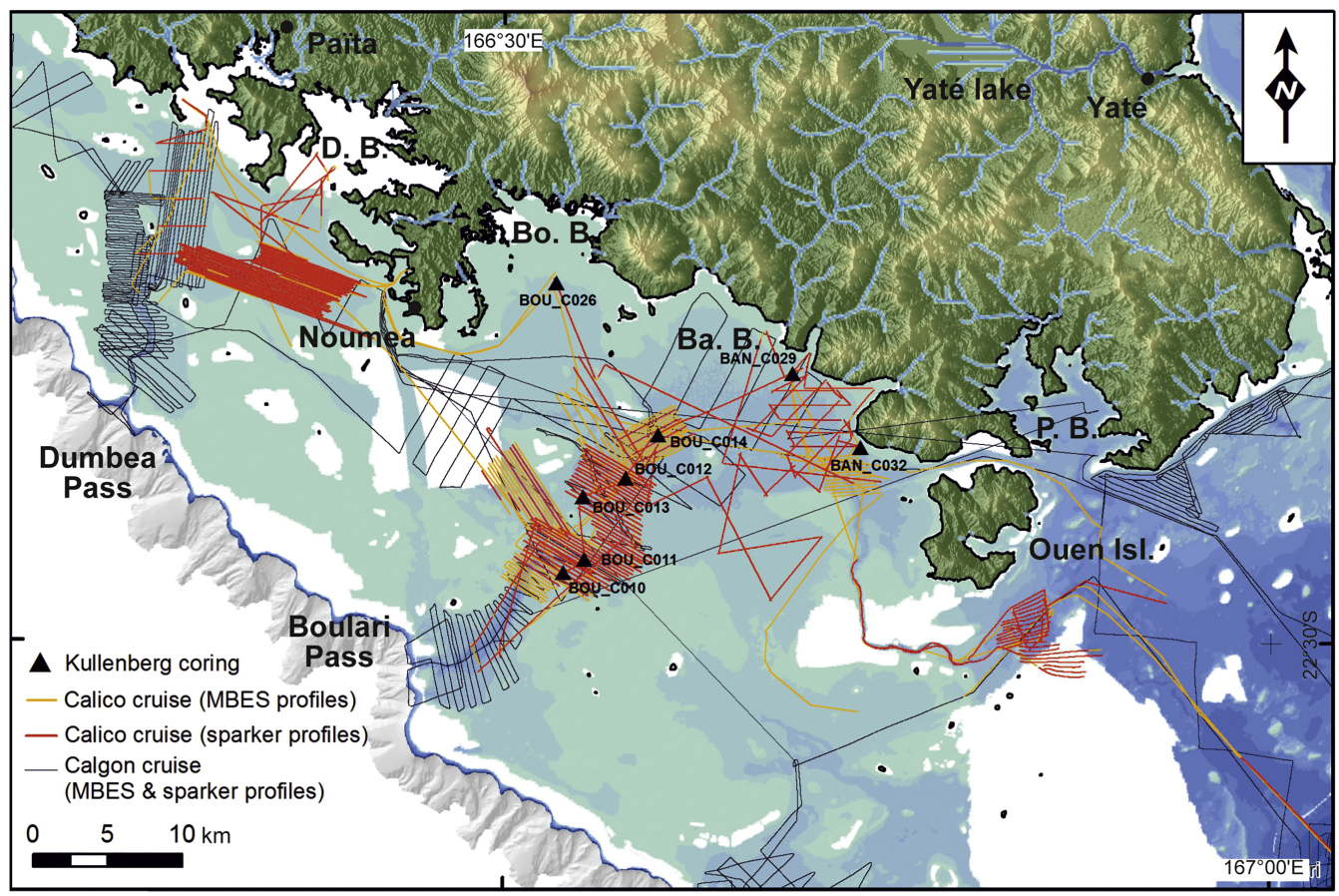

Figure 2 


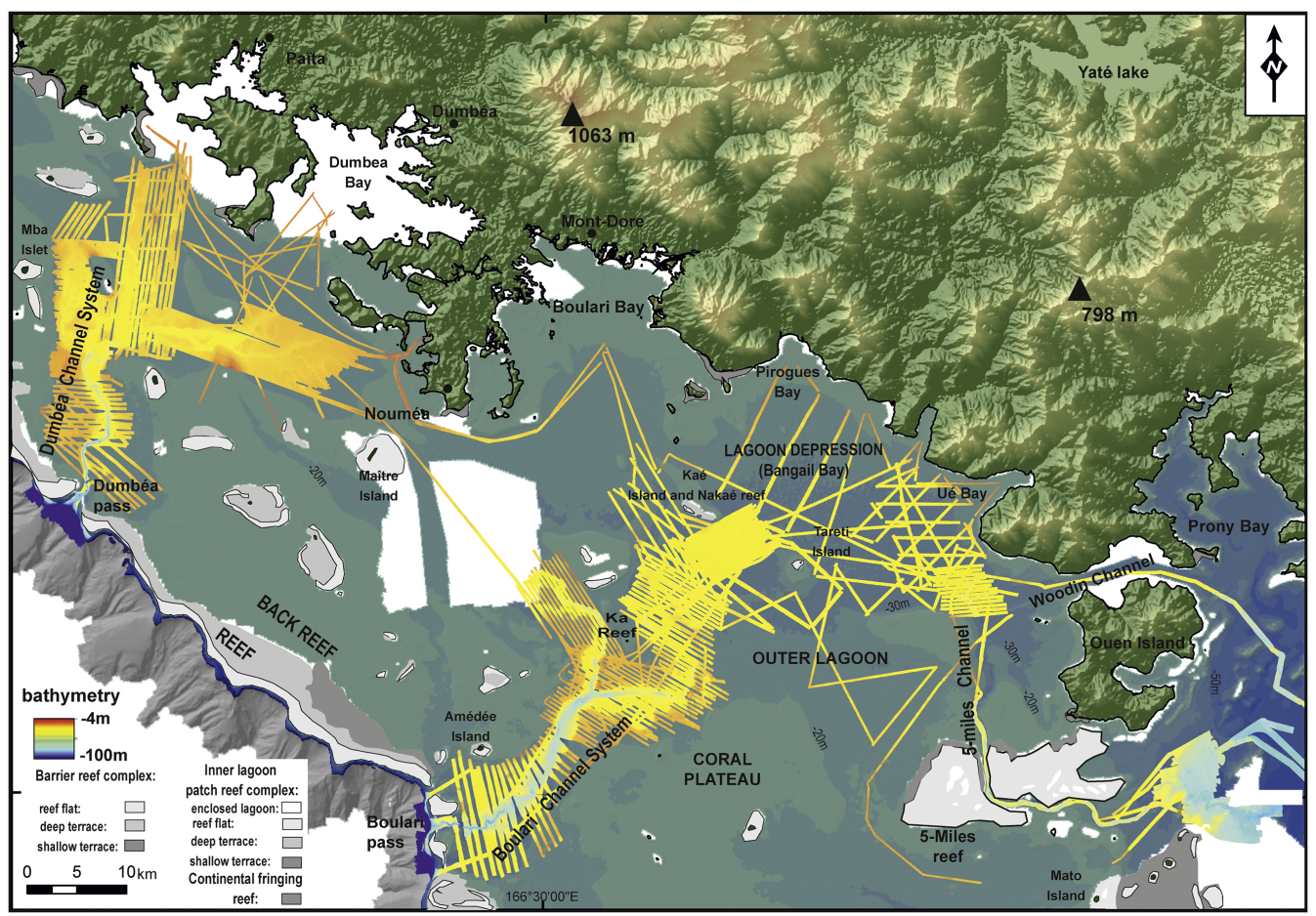

Figure 3 


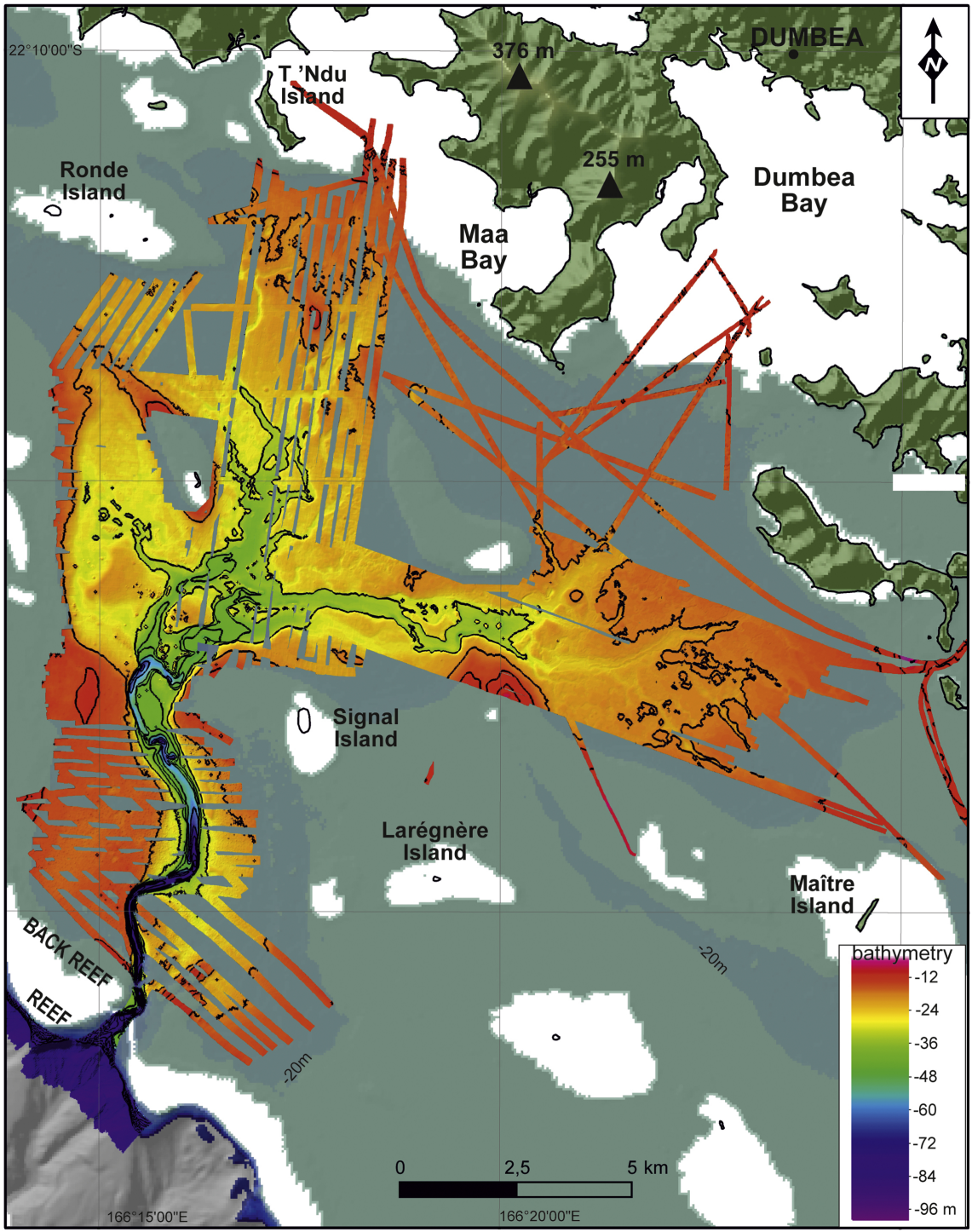




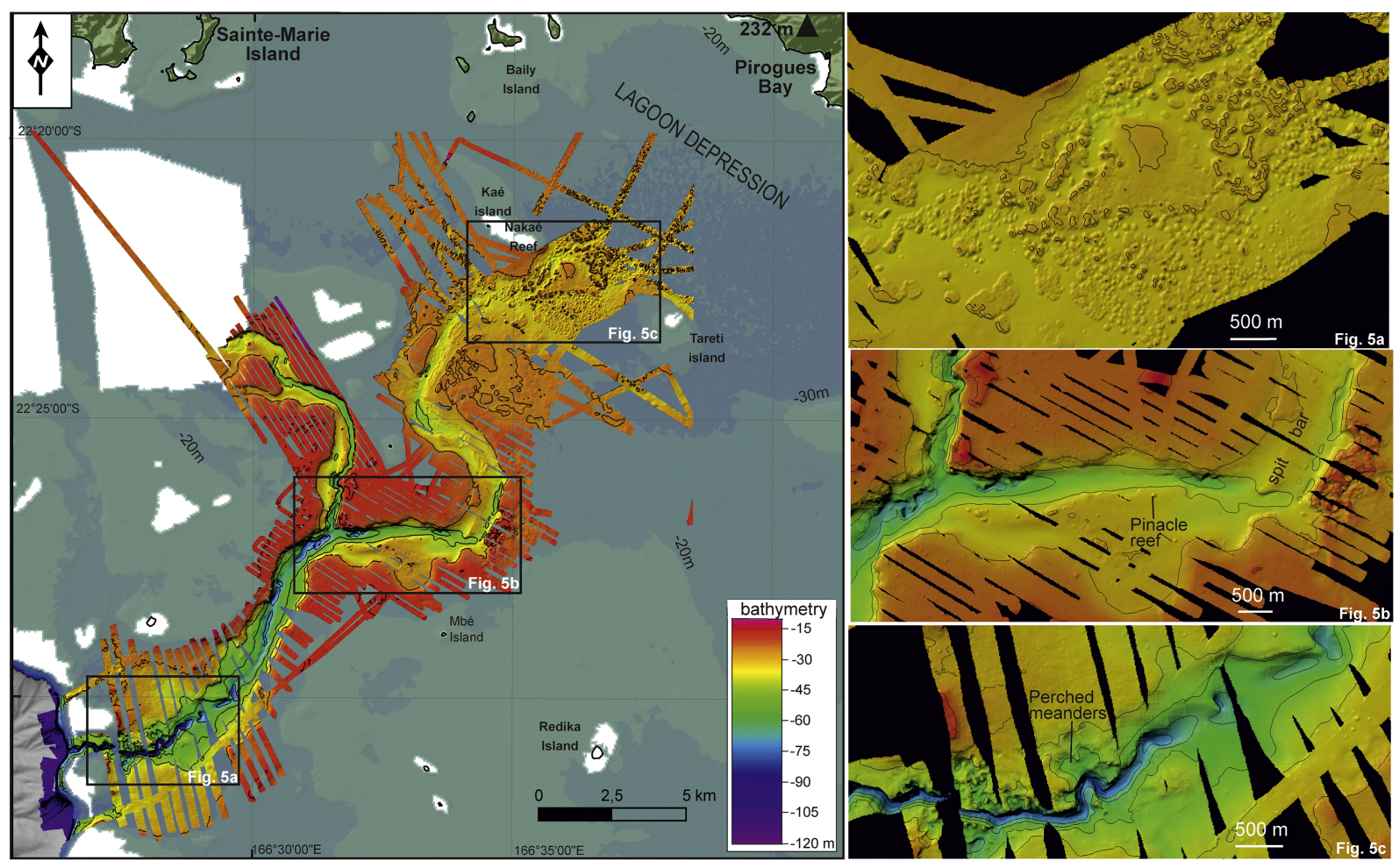

Figure 5 


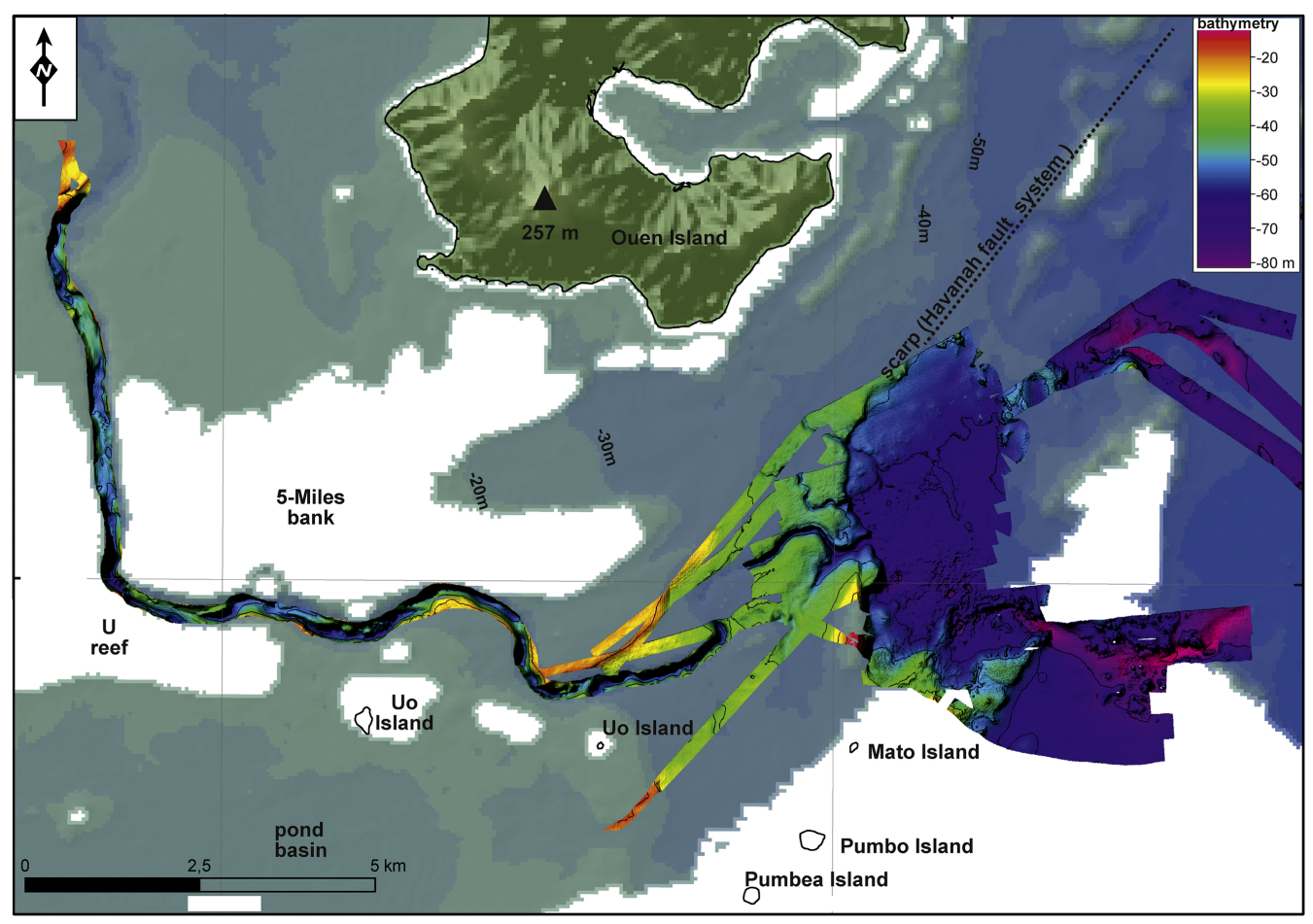

Figure 6 


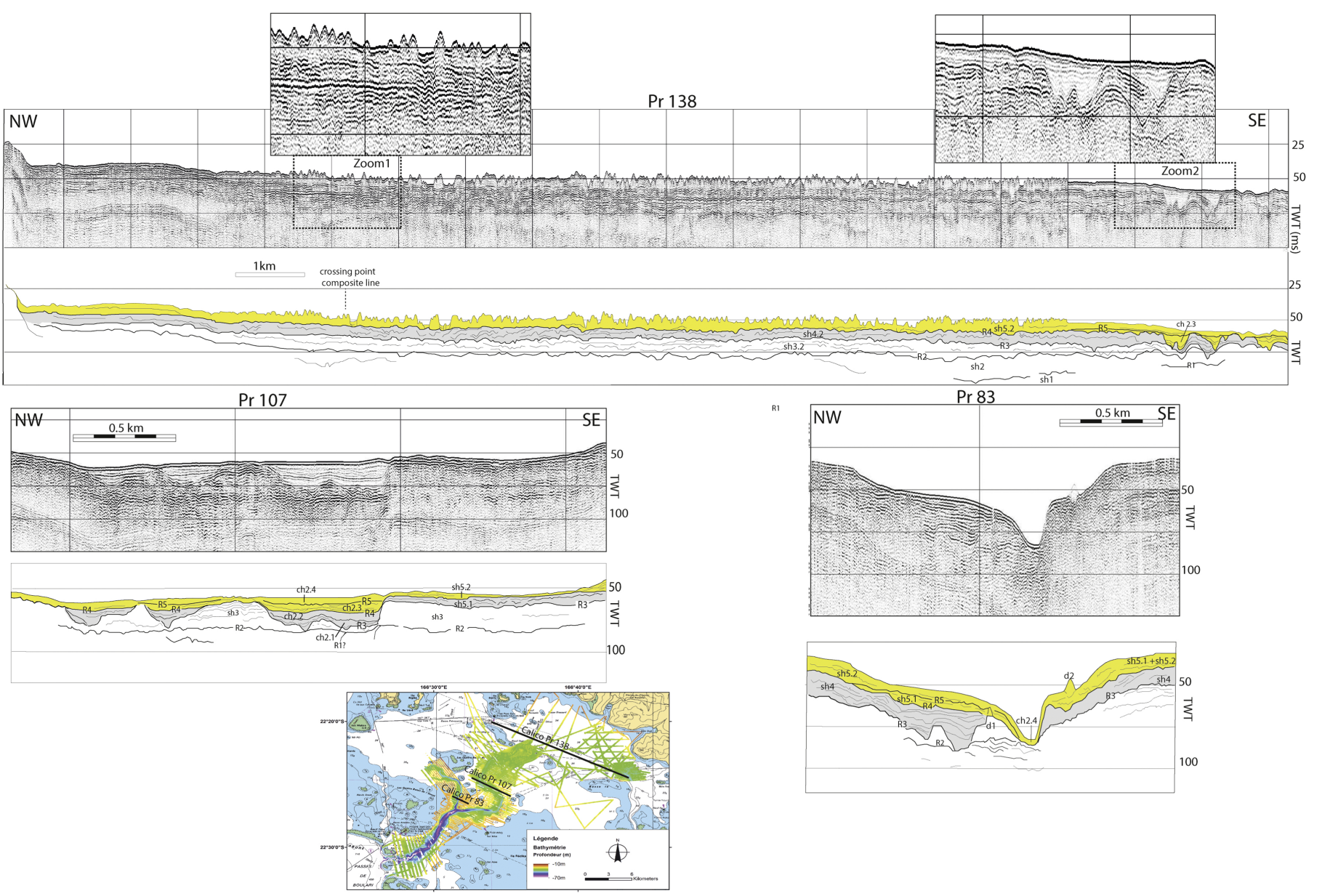

Figure 7 

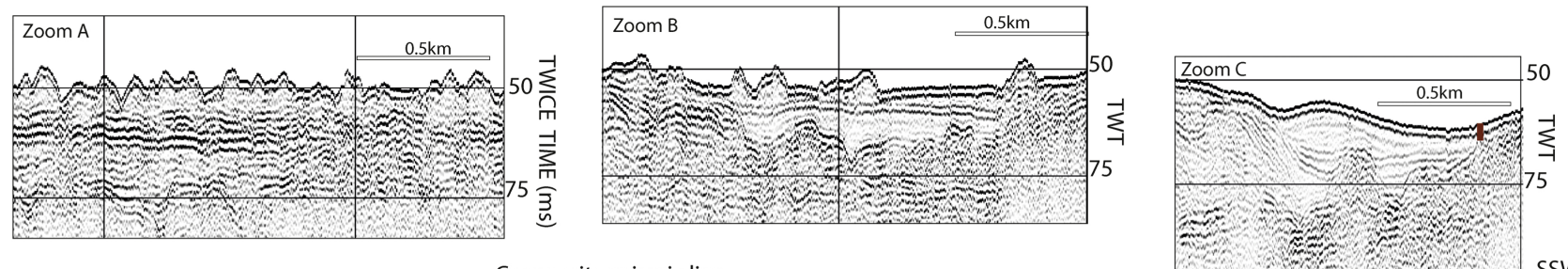

NNE

Crossing point Pr 13

Composite seismic line Crossing point Pr 107

CALBAN_C229 ZOOmA:

CALBAN_C2929 ZOOmA:

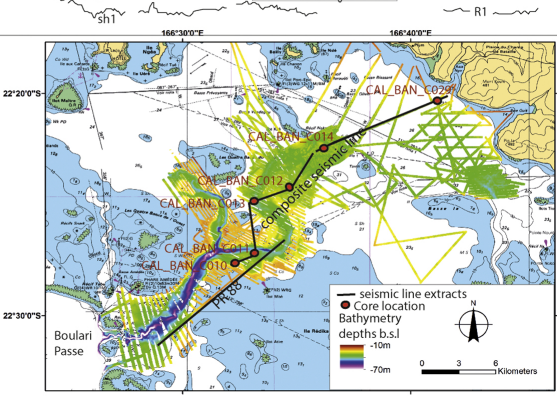
in tint
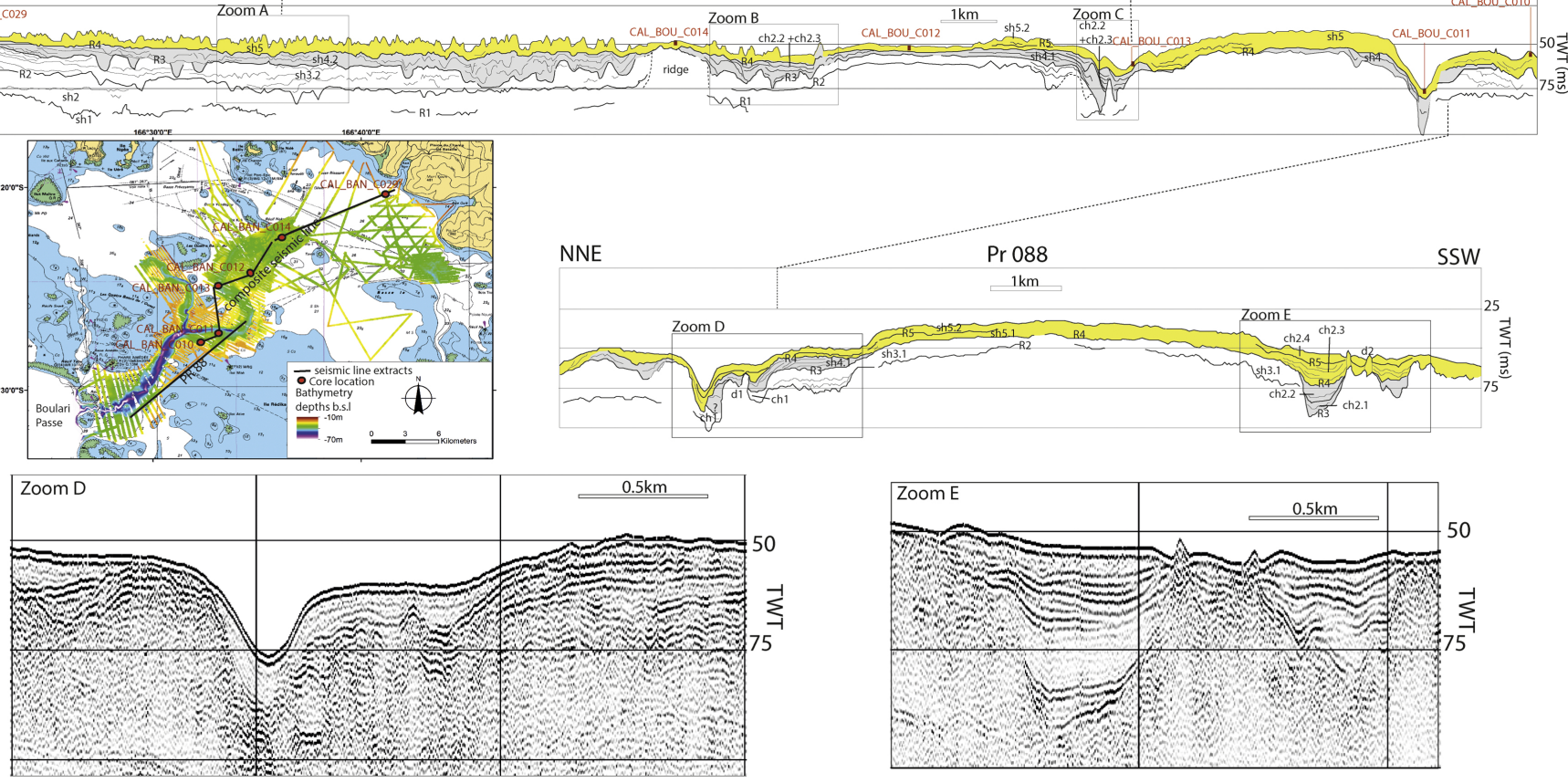

Figure 8 

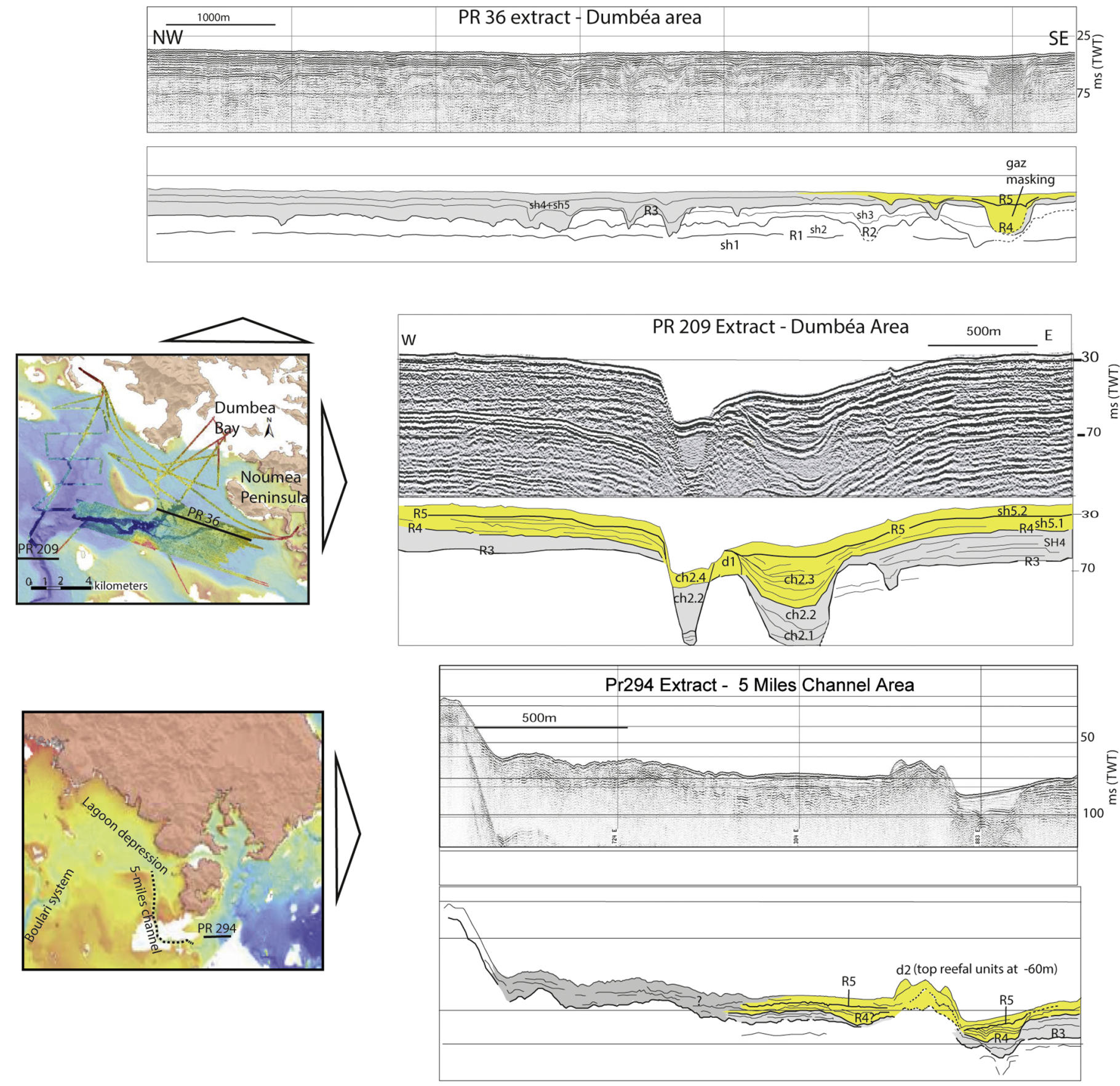

Figure 9 


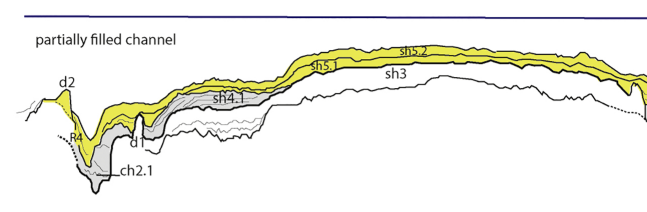

filled channel

bioherms domes
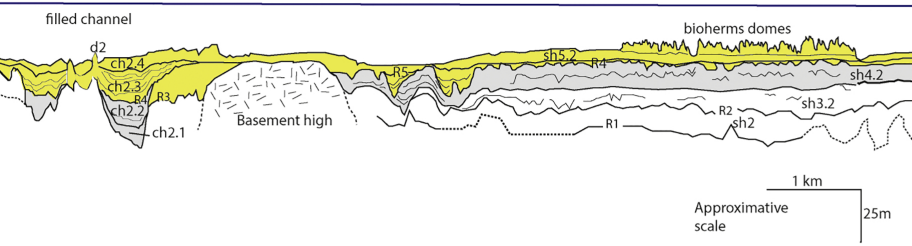

B

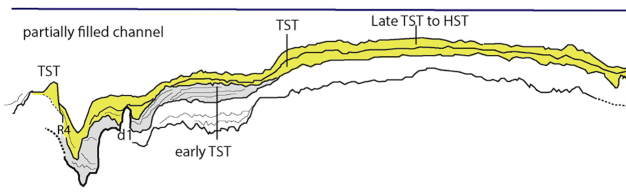

ravinement

ravinement sur

${ }^{2}$ Late TST HST MFS

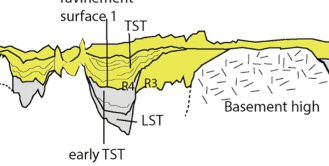
ravinement surface

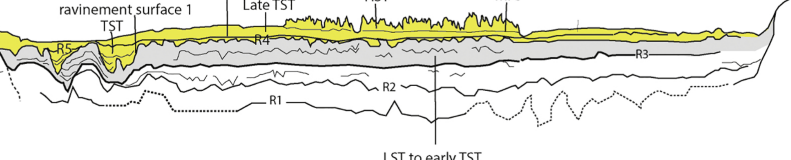

LST to early TST
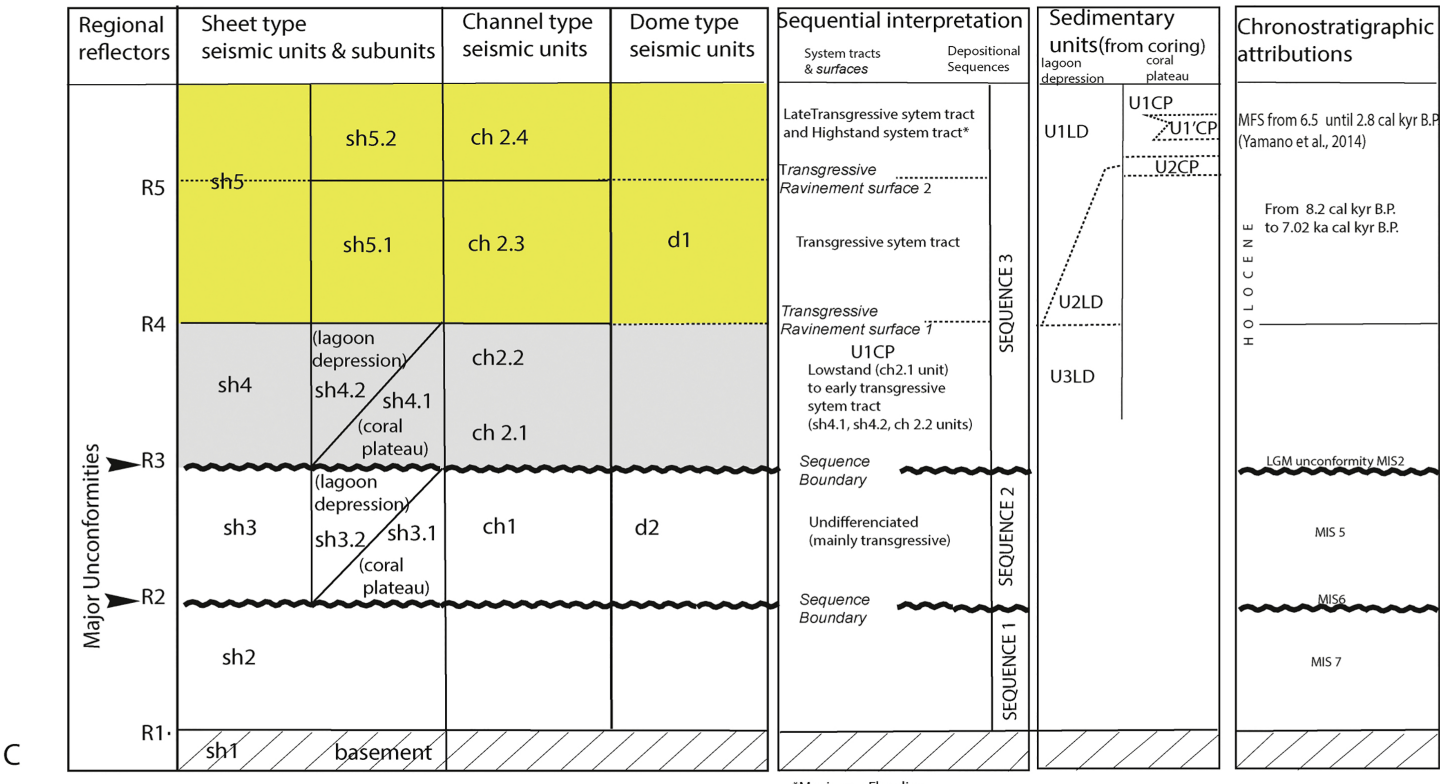

${ }^{*}$ Maximum Flooding

Surface (not visible on seismic) 


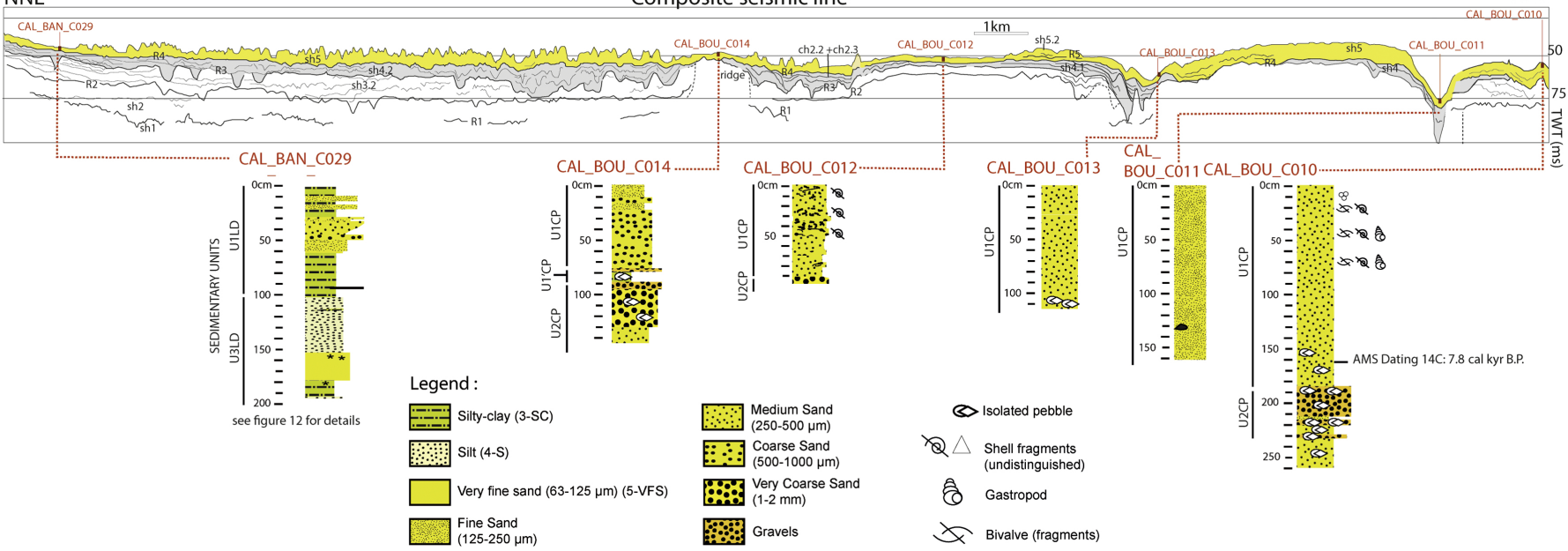

Figure 11 

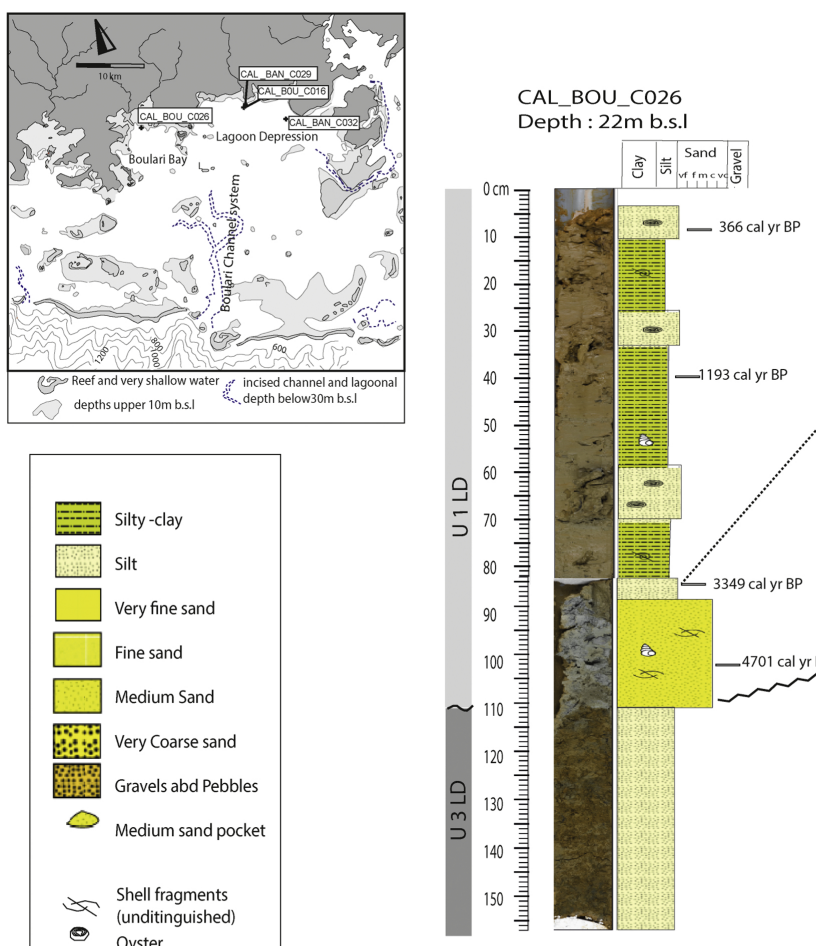

CAL_BAN_C029
Depth : $28 \mathrm{~m}$ b.s.I

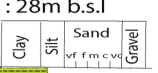

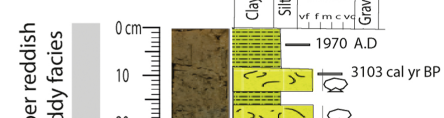

$\frac{10}{3-1} 18$

\begin{tabular}{|c|c|}
\hline & Silty-clay \\
\hline & Silt \\
\hline & Very fine sand \\
\hline & Fine sand \\
\hline & Medium Sand \\
\hline 80 & Very Coarse sand \\
\hline 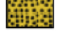 & Gravels abd Pebbles \\
\hline$\infty$ & Medium sand pocket \\
\hline$x$ & $\begin{array}{l}\text { Shell fragments } \\
\text { (unditinguished) }\end{array}$ \\
\hline (2) & Oyster \\
\hline (6) & Gastropod \\
\hline K & Large shell fragments \\
\hline 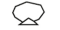 & Pecten \\
\hline$\star$ & Organic Matter \\
\hline - & Charcoal Debris \\
\hline U & Bioturbations \\
\hline
\end{tabular}

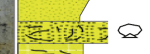

CAL_BAN_C032

Depth : $28 \mathrm{~m}$ b.s.I

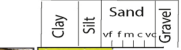

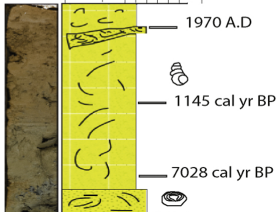
$\equiv \leqslant$
윽 로

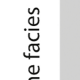

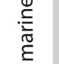

:

30 毒

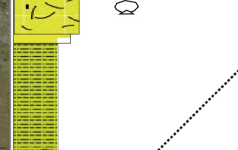

Oे

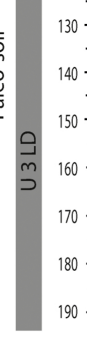

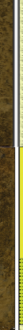

—

$\overline{1}=0$

E=
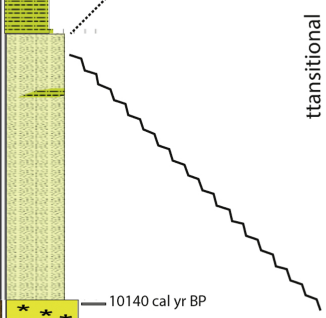

Seismic R4=

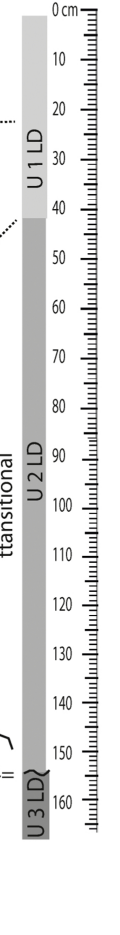

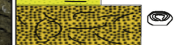

W

Wury v

(p)pyp

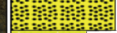
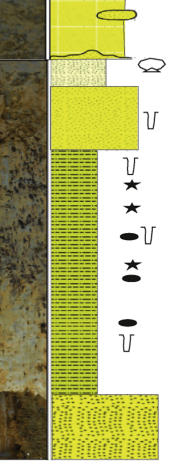

Figure 12 


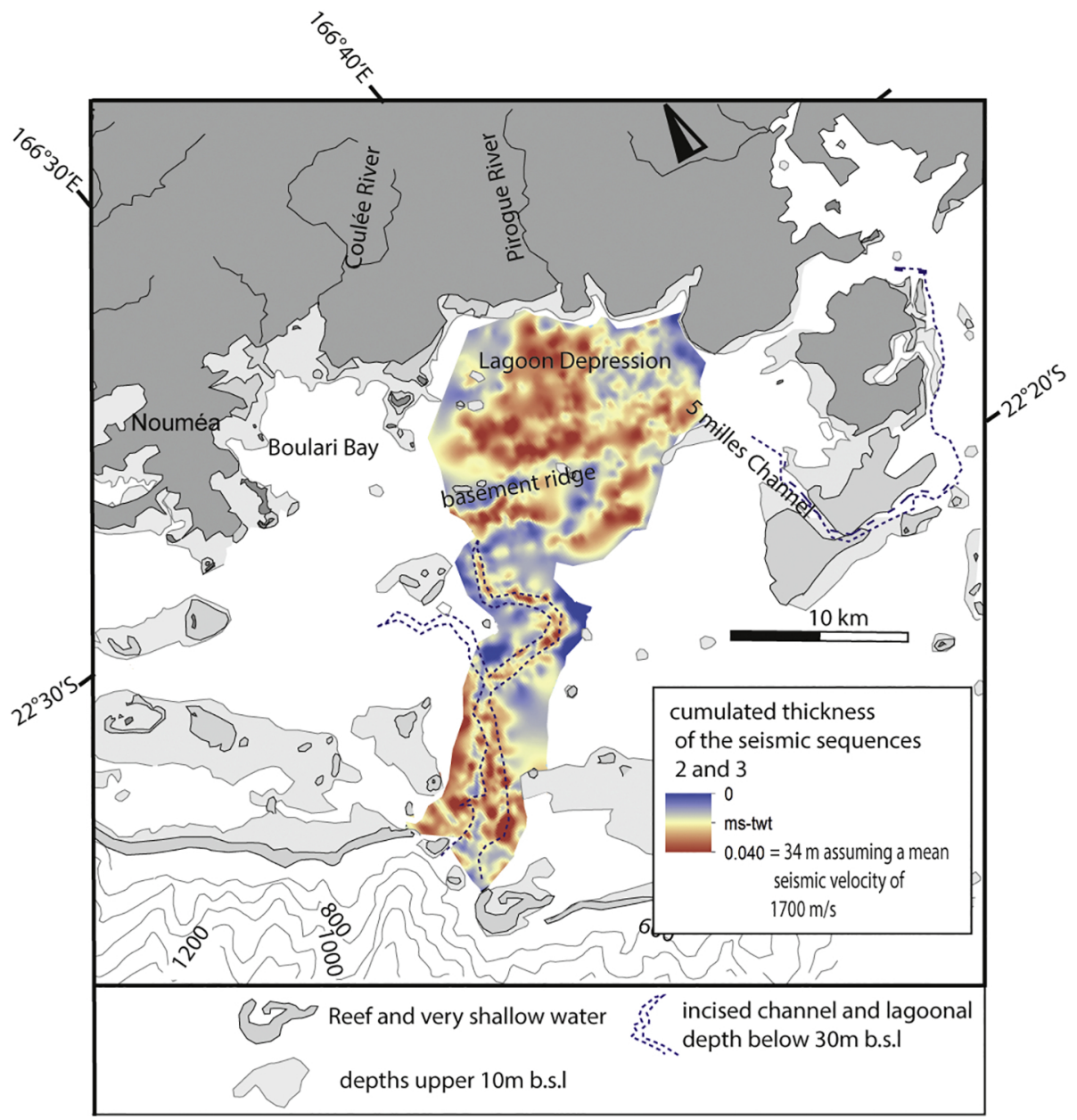




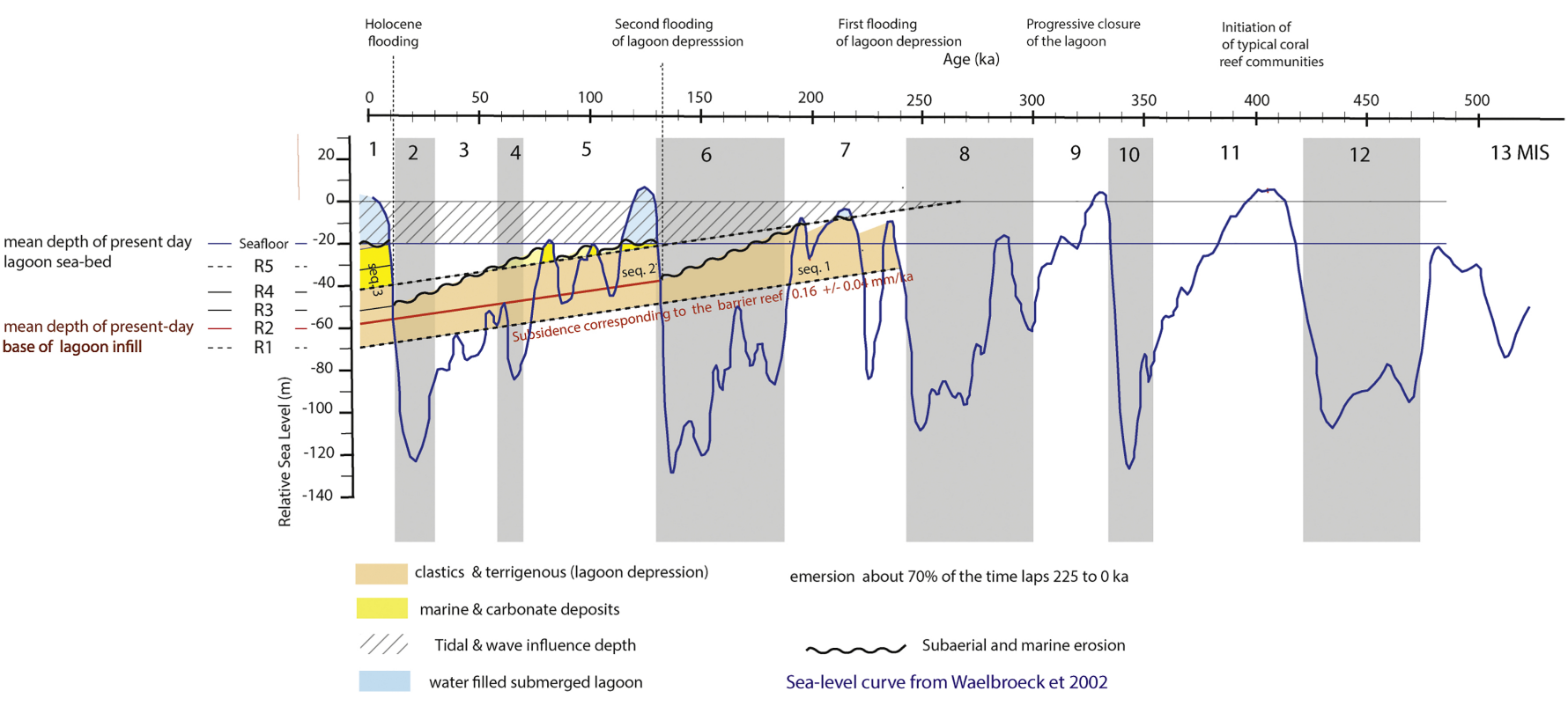


bioherms (oysters and scleractinian corals)

buried by reddish terrigenous silty to sandy deposits after 4 cal kyr B.P.

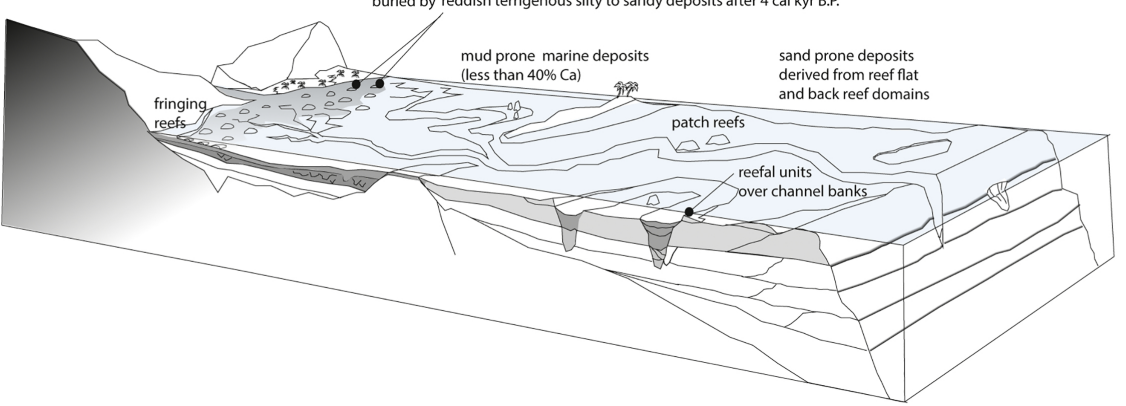

Stage $3: 7$ cal kyr B.P to present-day Maximum flooding stage and terrigenous clastic input

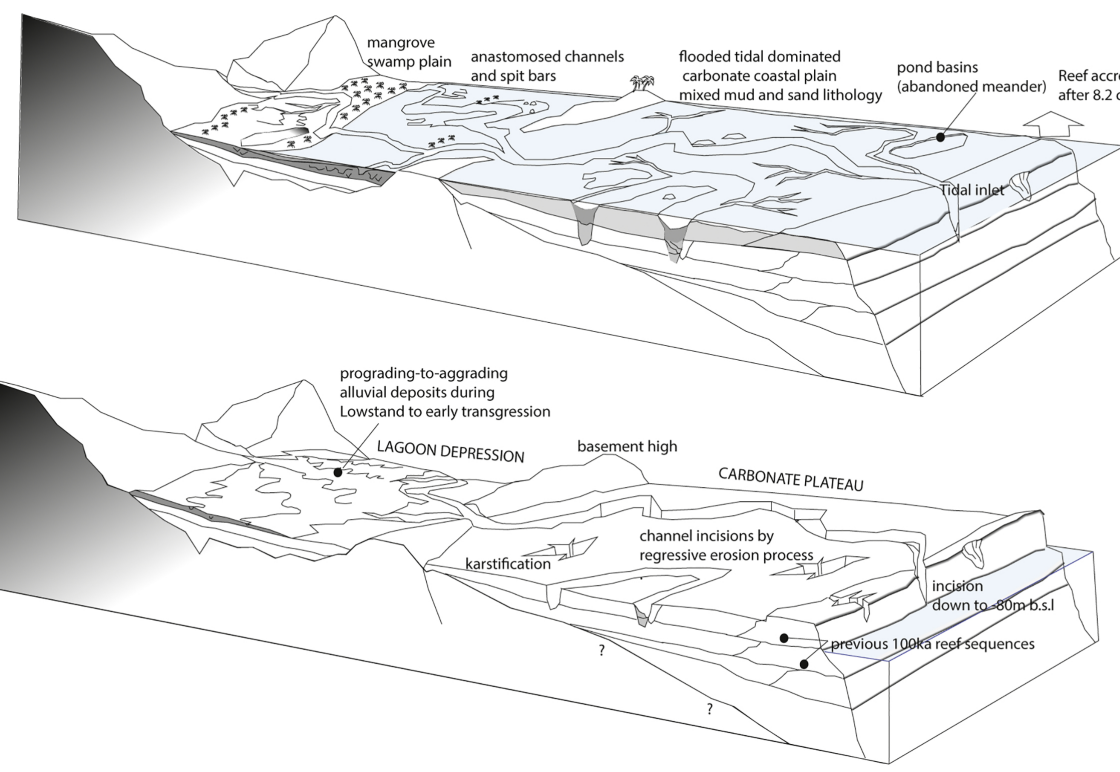

Stage 2 : from 12 to 7 cal kyr B.P. progressive flooding of the shelf.

Stage 1: MIS 2

the entire shelf remains emerged until 12 cal kyr B.P. 


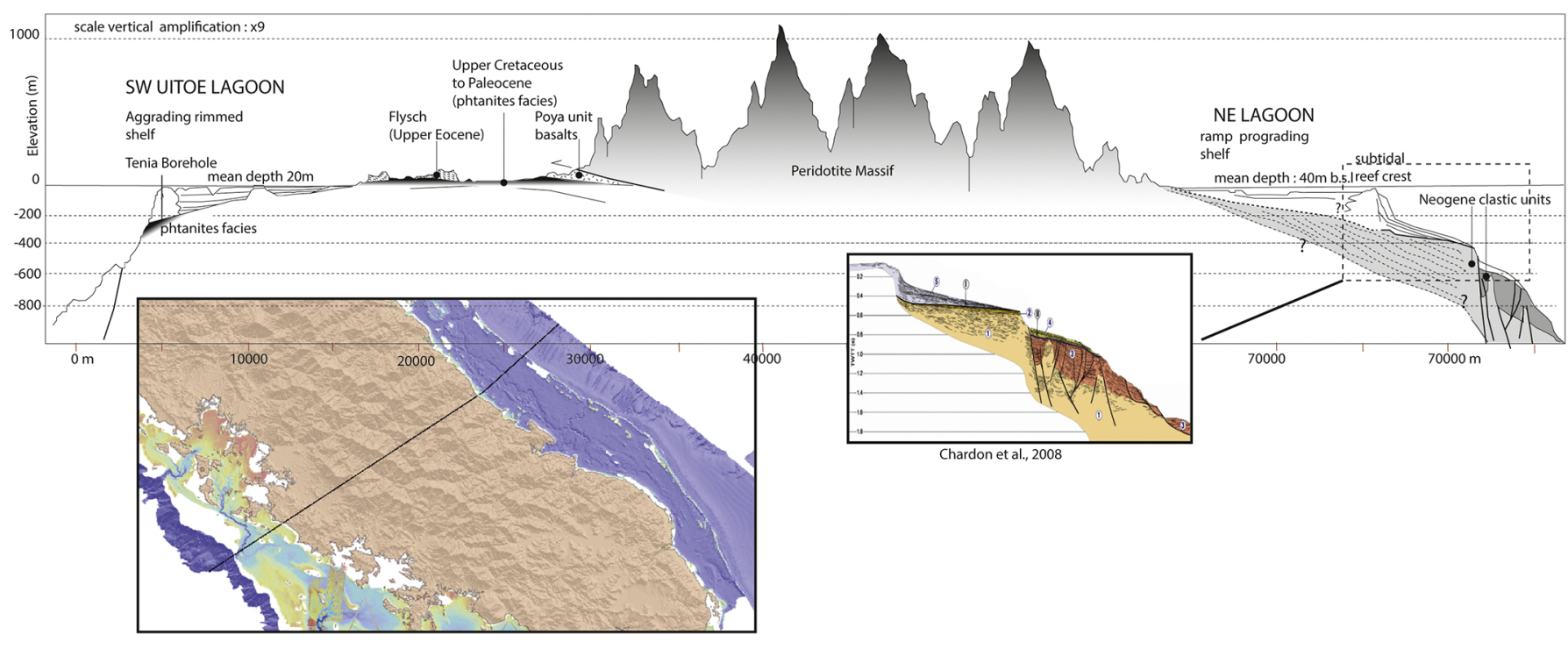

Figure 16 